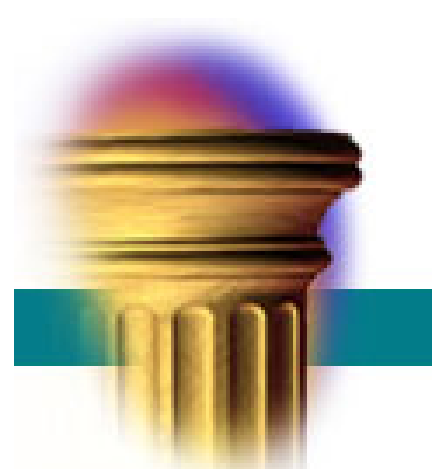

\title{
0 on \\ The Effects of the Great Migration on Urban Renewal
}

Ying Shi, Daniel Hartley, Bhaskar Mazumder, and Aastha Rajan

\author{
REVISED \\ March 17, 2021
}

WP 2021-04

https://doi.org/10.21033/wp-2021-04

${ }^{*}$ Working papers are not edited, and all opinions and errors are the responsibility of the author(s). The views expressed do not necessarily reflect the views of the Federal Reserve Bank of Chicago or the Federal Reserve System. 


\title{
The Effects of the Great Migration on Urban Renewal*
}

\author{
Ying Shi \\ Syracuse University \\ Daniel Hartley \\ Federal Reserve Bank of Chicago \\ Bhash Mazumder \\ Federal Reserve Bank of Chicago \\ Aastha Rajan \\ Federal Reserve Bank of Chicago
}

March 2021

\begin{abstract}
The Great Migration significantly increased the number of African Americans moving to northern and western cities beginning in the first half of the twentieth century. We show that their arrival shaped "slum clearance" and urban redevelopment efforts in receiving cities. To estimate the effect of migrants, we instrument for Black population changes using a shift-share instrument that interacts historical migration patterns with local economic shocks that predict Black out-migration from the South. We find that local governments responded by undertaking more urban renewal projects that aimed to redevelop and rehabilitate "blighted" areas. More Black migrants also led to an increase in the estimated number of displaced families. This underscores the contribution of spatial policies such as urban renewal towards understanding the long-term consequences of the Great Migration on central cities and Black neighborhoods and individuals.
\end{abstract}

${ }^{*}$ We are especially grateful to Justin Madron, Brent Cebul, and the Digital Scholarship Lab team at the University of Richmond for the dataset on urban renewal projects with accompanying shapefiles. The views expressed here do not necessarily represent the views of the Federal Reserve Bank of Chicago or the Federal Reserve System. 


\section{Introduction}

The Great Migration instigated a drastic shift in the racial composition of American cities. Between 1940 and 1970, over four million African Americans left the South and settled in the North and the West. Previous studies suggest that there were substantial economic gains experienced by Blacks who migrated during this period (Collins and Wanamaker, 2014; Boustan, 2017). On the other hand, research document negative consequences on the well-being of Black migrants ranging from health (Black et al., 2015) to an increased probability of incarceration (Eriksson, 2019).

New work exploring the long-term consequences of the Great Migration suggest that negative effects extend to Black descendants of the original migrants. Derenoncourt (2020) finds significant detrimental effects on the upward mobility prospects of Black children born around 1980 who grew up in cities that were more affected by the Migration. Her study suggests that this was due to responses of local municipalities that received large in-flows of Black migrants rather than any compositional effects stemming from selective migration. For instance, cities more affected by the Great Migration increased spending on police and incarceration. This emphasis on the role played by cities echos Boustan (2010)'s finding that mid-century Black geographic mobility affected the responses of local governments in ways that induced White flight.

One aspect of the response of cities that has received less attention in the literature is the role of housing, land redevelopment, and related spatial policies. We show that cities receiving high inflows of Black migrants due to plausibly exogenous factors, exhibited a marked increase in the likelihood of ever initiating an urban renewal project as well as an increase in the total number of such projects undertaken. Urban renewal programs were federally subsidized local efforts aimed at clearance of "blighted" urban neighborhoods for redevelopment and rehabilitation. The program began in 1949 with the creation of the Federal Housing and Home Finance Agency that offered cities significant financial support for redevelopment projects. The use of eminent domain as delegated by state governments enabled local municipalities to clear residential areas, accompanied often by the planned displacement and relocation of families.

To estimate the causal effect of the Great Migration on cities' urban renewal policies, we adopt an empirical approach based on the Bartik or shift-share instrument commonly used in the trade and migration literatures (Altonji and Card, 1991; Card, 2001). The fundamental identification 
challenge is that migrants select into destinations outside of the South based on factors such as local demand conditions. A valid instrument for Black migration inflows into northern cities must not affect local demand conditions and other city-level shocks except via predicted inflows. To construct such an instrument, we rely on an interaction between historical settlement patterns of Black migrants and so-called "push factors," or local economic conditions in Southern sending cities. Boustan (2010) was the first to apply this instrument to the Great Migration context and our implementation closely follows that of Derenoncourt (2020).

The analysis relies on a sample of the largest 713 cities by population in the northern and western United States, with corresponding actual and predicted inflows of Black migrants based on the instrumental variables strategy described above. Data on urban renewal efforts come from the Digital Scholarship Lab at the University of Richmond and are based on federal directories of urban renewal project timing, funding, and attributes. As far as we are aware, this dataset provides the most comprehensive record of urban renewal activity to date. Overall, we are able to link data on inflows of Black migrants across our sample of cities to rich information on urban renewal projects as well as other related spatial policies.

We find that cities that experienced an increase in Black migration were significantly more likely to undertake at least one urban renewal project. A 10-percentile point increase in actual Black migration led to a 10 percentage point increase in ever having had an urban renewal project between 1955 and 1974 and an increase of approximately 0.2-0.3 projects per 5-year period during this time span. We also document significant effects on family displacement. A city that is at the 90th percentile in terms of Black migration would plan to displace an additional 310 White families and 710 non-White families relative to a city at the 10th percentile of Black migrants during 19401950. Furthermore, we find significant effects on receiving Federal housing assistance and public spending on housing and community development from having greater inflows of Black migrants. When examining other specific components of public spending, we find positive effects on public expenditures on police (as in Derenoncourt (2020)) but we also find negative effects on spending on public utilities which could be suggestive of a deterioration in housing conditions.

Our study contributes to several strands of literature. Despite the historical prominence of urban renewal, there are very few studies in economics on these policies. While we examine urban renewal efforts in response to Black arrivals, existing work focus on the effect of urban renewal 
on neighborhoods and cities. Collins and Shester (2013) find positive effects of urban renewal in aggregate city-level data on income, property values, and population. ${ }^{1}$ LaVoice (2019) uses a sample of the largest 28 cities to document increasing neighborhood rents and incomes that are accompanied by a reduction in affordable housing, suggesting that disadvantaged families are made worse off by urban renewal policies. LaVoice (2019) also finds that Black neighborhoods were disproportionately more likely to be targeted for "slum clearance" and redevelopment even after accounting for the extent of "blight". These findings echo the concerns of urban renewal programs raised in the broader literature, including the relocation of families and lack of quality replacement housing, the disproportionate impact on low-income Black families, and loss of cohesive neighborhoods and social capital (Johnstone, 1958; Wilson, 1966; Anderson, 1967; Hoffman, 2000; Fullilove, 2001). We contribute to the literature by asking whether these programs were undertaken in response to increasing numbers of Black arrivals as part of the Great Migration.

In doing so, our paper builds on a growing literature on the effects of the Great Migration on both the migrants themselves as well as their descendants. Previous studies suggest that negative consequences for Black migrants and their progeny arise from a decline in the quality of the urban environment for families (Boustan, 2010; Derenoncourt, 2020). Spatial policies such as urban renewal and land redevelopment played a key role during the middle of the twentieth century in shaping central cities and their inhabitants (Ammon, 2016). Urban renewal often took place contemporaneously with land clearance for highway construction projects, which in turn facilitated population departure into the suburbs (Baum-Snow, 2007). A closer examination of the influence of urban renewal and related spatial policies may shed light on recent findings of decreased social mobility resulting from the Great Migration (Derenoncourt, 2020), as well as clarify their potential contribution to the influence of neighborhood effects on intergenerational mobility (Chetty and Hendren, 2018a,b).

\footnotetext{
${ }^{1}$ Collins and Shester (2013) assess whether cities with more urban renewal funding experienced more rapid economic growth as of 1980. For identification, they use an IV strategy that exploits variation among states in the timing of when states had passed enabling legislation that would allow for the exercise of eminent domain. Such legislation was crucial for the ability to implement a project and the timing of such legislation is arguably due to idiosyncratic factors and thus might be viewed as plausibly exogenous. They find that the effects of urban renewal programs were positive for income, property values, and population. Nevertheless they caution that this finding does not mean that the dislocation costs for residents and businesses were unimportant and they do not implement a full cost-benefit analysis.
} 


\section{Background}

\subsection{The Great Migration}

The Great Migration was one of the most important demographic events in American history. It led to a dramatic redistribution of the African American population from the South to urban locations in the North and West that provided substantially better economic and social opportunities. Black individuals were motivated to leave the South by both push and pull factors. Declining opportunities to work in agriculture in the South, coupled with an increase in manufacturing outside the South, were prominent factors. Recent research has shown that Black migration was facilitated by greater educational opportunities (Aaronson and Mazumder, 2011), social networks (Stuart and Taylor, 2019) and access to trains (Black et al., 2015).

In the first phase of the Great Migration, between 1910 and 1940, approximately 1.5 million Black individuals left the South. ${ }^{2}$ The second phase, between 1940-1970, was substantially larger as it resulted in four million additional migrants. As a result, the Black share of residents in the major receiving cities of New York, Philadelphia, Chicago, Detroit, and Los Angeles increased from just 3\% in 1910 to $26 \%$ by 1970 (Collins, 2020). This seminal event had long-lasting social and economic ramifications. Boustan (2017) notes that southern migrants went to urban locations that were characterized by tight and racially segmented labor markets and a limited supply of housing. This led to a substantial degree of White flight to the suburbs thereby fundamentally transforming these cities.

Previous research has shown that Black migrants roughly doubled their earnings by leaving the South (Collins and Wanamaker, 2014; Boustan, 2017). In recent work, Baran et al. (2020) show that the children of migrants also experienced higher educational attainment. However, these gains for migrants also came at the cost of a higher risk of mortality (Black et al., 2015) and a higher probability of incarceration (Eriksson, 2019).

\footnotetext{
${ }^{2}$ Figure 1 shows the number of Black migrants relocating to northern and western cities from the south at the end of this first phase during 1935-1940.
} 


\subsection{Urban Renewal}

The federal government assumed an increasingly prominent role in public housing and urban redevelopment during the 1930s and 1940s, in the aftermath of the Great Depression and World War II (Gelfand, 1975; Fogelson, 2001). One particularly salient issue was the potential spread of "slums" or areas of "urban blight." The expanding constituency in support of "slum clearance" included local officials, central city business interests, and low- and moderate-income housing advocates, yet attempts to redevelop these areas ran up against land assembly and cost issues (Teaford, 2000; von Hoffman, 2000). Concerns around the lack of legal power and financial resources accelerated calls for a centralized planning authority and federal subsidies for urban redevelopment (Wilson, 1966).

In 1949, as part of the unveiling of his Fair Deal agenda, President Truman mentioned in his State of the Union address that "five million families are still living in slums and firetraps". That same year the American Housing Act was passed and Title I of the law provided federal financing for "slum clearance" programs associated with urban redevelopment projects. The Act enabled the Housing and Home Finance Agency (HHFA), which was the precursor to HUD, to support local governments by providing grants of two-thirds of the net cost of acquiring and clearing properties (Collins and Shester, 2013). ${ }^{3}$

The process of initiating an urban redevelopment project begins with a Local Public Agency (LPA) that is permitted under state law to exercise eminent domain (Collins and Shester, 2013). The LPA would identify an area characterized by "blight" and then acquire the land for redevelopment (LaVoice, 2019). The LPA would then hold public hearings, obtain local approval, and ultimately permission from the HHFA in order to begin the planning process.

Title I in the Housing Act of 1949 relied primarily on large-scale demolition and rebuilding. While complete clearance was the predominant mode of addressing so-called "slums", there was increasing support for conservation and rehabilitation as an alternative approach (Wilson, 1966). Reforms to the original legislation came in the Housing Act of 1954, which expanded the program to include conservation of existing historical structures, building code enforcement, and relocation

\footnotetext{
${ }^{3}$ The net cost is the difference between the cost of acquiring land and its reuse value. Local governments needed to repay the remaining one-third, but were allowed to do so in cash or in kind (von Hoffman, 2000).
} 
of displaced families (Wilson, 1966). ${ }^{4}$ As a result, the amount of land clearance varied greatly from project to project, and funded projects expanded from largely residential to also include nonresidential structures such as office buildings and stadiums (von Hoffman, 2000).

The pace of urban renewal escalated quickly, from a total of 31 communities in 1950 to 772 by mid-1965, when nearly 1,600 projects were underway (Wilson, 1966). Taken together, more than $\$ 5$ billion were authorized for urban renewal and nearly two thousand projects were approved by the federal government in the first two decades of its operation (National Commission on Urban Problems, 1969; von Hoffman, 2000).

Over time, the urban renewal program came under increasing criticism. Some pointed to its role in reducing the scope of affordable residential housing. A survey of 1,155 urban renewal projects in 1966 found that while two-thirds were predominantly residential before the project began, only 43\% remained so afterwards (National Commission on Urban Problems, 1969). The same report found that even when new construction was for residential purposes, the increase in rent frequently priced out former occupants.

The burden of displacement also fell disproportionately on communities of color as $54 \%$ of displaced families were non-White (of Housing and Urban Development, 1967). Some argued that urban renewal was a tool used to level Black neighborhoods under the guise of economic development (Hirsch, 2000; Fullilove, 2001). Opponents argued that these projects decreased the already scarce stock of affordable housing for Black families and preserved a pattern of racial segregation (Teaford, 2000). These critiques were joined by conservative voices emphasizing diminished personal liberty as a result of expanded federal authority (Anderson, 1967). The mounting criticism and popular discontent in the 1960s and early 1970s led to the end of the urban renewal program in 1974 (Teaford, 2000).

\footnotetext{
${ }^{4}$ The term "urban renewal" comes from the 1954 Act, signaling a more comprehensive approach beyond "urban redevelopment."
} 


\section{Data and Descriptive Statistics}

\subsection{City Characteristics}

The sample of receiving cities comes from the complete count 1940 Census and the 1944-1977 County and City Data Book. We restrict to cities with a population of at least 10,000 outside of the South, which excludes the states of Alabama, Arkansas, Florida, Georgia, Kentucky, Louisiana, Mississippi, North Carolina, Oklahoma, South Carolina, Tennessee, Texas, Virginia, and West Virginia. The final sample contains 713 cities.

City-level population estimates come primarily from the 1940 Census with supporting information from the County and City Data Book. The Black population count in 1940 also comes from the 1940 Census. Corresponding Black population data in 1950 comes from the 1950 Census of Population, which describes racial demographics for cities with a population of 10,000 or more. This enables the calculation of 1940-1950 changes in local Black populations. Finally, city-level characteristics such as the share of the labor force in manufacturing come from the 1940 complete count Census.

\subsection{Urban Renewal Projects and Interstate Construction}

Our database of urban renewal projects comes from the Digital Scholarship Lab at the University of Richmond. Project characteristics with the exception of funding data come from the federal government's Urban Renewal Project Characteristics issued quarterly from 1955 to 1966. These reports are drawn from information submitted by local public agencies to meet Housing and Home Finance Agency requirements for the planning and implementation of urban renewal projects. Project-level attributes include the project's name, date, city, federal funding amount, acreage, number of standard and substandard dwelling units to be demolished, and number of White and non-White families residing in the designated project areas. Note that the number of White and non-White families in these documents reflect estimated displacements as reported to the federal government by local municipalities. ${ }^{5}$ Similarly, data on dwelling units show an estimate of the number of standard and substandard units targeted in the areas to be cleared for development.

\footnotetext{
${ }^{5}$ Our estimates likely are an undercount of true displacement. Federally-funded urban renewal projects continued for eight additional years, but we only have estimated displacement information through 1966. Moreover, data exists only for families, not displaced individuals.
} 
Funding data comes from the annual Urban Renewal Directory reports issued by the U.S. Department of Housing and Urban Development. It includes both the federal grants approved for a particular project as well as the final disbursed amount from 1957-1974. Dates on the projects' planning and execution come from both Urban Renewal Project Characteristics and Urban Renewal Directory. For projects observed multiple times in the federal records, we take the most recent observations of project attributes and funding. We then collapse observations from the project to the city level. We merge this dataset with the base sample of 713 cities to determine the prevalence of cities with at least one urban renewal project.

We supplement urban renewal data with information on interstate highway construction. We follow Baum-Snow (2007) in identifying the completion date of each segment of federally-funded interstate. We overlay digital maps of city boundaries to calculate the miles of interstate constructed by a given year. These measures of construction progress allow us to determine whether in-migration affected spatial policies in central cities that were taking place contemporaneously alongside urban renewal. ${ }^{6}$

\subsection{Local Public Finance}

Information on local government revenues and expenditures come from historical Census files. We begin with municipal or city-level public finances before supplementing with county arealevel finances collected by the Census Bureau. The latter aggregates the local finances of counties, cities/municipalities, townships, special districts, and independent school districts. As such they represent all local revenues and expenditures exclusive of state and federal activities.

County area finance data spans censuses of governments conducted in 5-year intervals. Since city-level finance data is also most comprehensive during these years, we focus on local government finance data from 1967 to $1987 .^{7}$ Censuses of government and city-level data from the Historical Database on Individual Government Finances (INDFIN) standardize reporting over time by revenue source and expenditure type. We compute per-capita revenues and expenditures in 1967, 1972, 1977, 1982, and 1987 using city or county populations from the corresponding years.

\footnotetext{
${ }^{6}$ Interstate construction in central cities significantly accelerated with the 1956 Interstate Highway Act, which increased the share of federal subsidies to 90 percent. Construction saw the greatest increase in the 1960s. Of the MSA interstate mileage completed as of 1990, only 22 percent were constructed by 1960 compared to 71 percent by 1970 (Baum-Snow, 2007).

${ }^{7}$ County-area finance data begin in 1972 due to limited data availability in 1967.
} 
We segment our analyses by source of revenue and type of expenditures. For example, we focus on intergovernmental revenue from the federal government directed towards housing and community development because this category covers federal subsidies for the construction or operation of public housing, rent subsidy programs, and urban or rural community development projects. On the expenditures side, we also focus on housing and community development because this category includes urban renewal activities. According to the Census classification manual on government finance, community development includes "urban renewal and slum clearance; redevelopment and rehabilitation of substandard or deteriorated facilities and areas; rural redevelopment; and revitalization of commercial areas. ${ }^{8}$ Other high-spending categories include but are not limited to utilities, education, and police protection.

\subsection{Descriptive Statistics}

Table 1 presents descriptive statistics for the sample of 713 cities. The average receiving city has a population of nearly 72,000 . This contrasts with the median population of over 22,000 due to a small cluster of large outlier cities. Cities saw an average increase in Black population of 2,720 individuals between 1940-1950. Two-thirds of cities in our sample had at least one urban renewal project. Figure 2 shows a high concentration of these projects in the urban northeast, as well as metropolitan areas such as Chicago and Detroit. The 481 cities with any urban renewal activity averaged 4.6 projects over the two-decade period spanning 1955-1974. The timing of these projects was fairly evenly distributed across time, with approximately one project every five years. The federal aid allocated towards these urban renewal efforts totaled 301 dollars per capita, of which half was eventually disbursed.

Many urban renewal projects involved the planned displacement of families. Participating cities planned to displace an average of 250 White families and 253 non-White families. The share of displacements made up by non-White families is less than the $54 \%$ reported by of Housing and Urban Development (1967), in part because the dataset restricts to cities outside of the South. As Table A1 shows using the full project-level sample, non-White families comprise over $56 \%$ in

\footnotetext{
${ }^{8}$ Housing encompasses "planning, construction, furnishing, and operation of public housing projects (generally for persons not adequately served by private sector); rent subsidies (e.g., "Section 8" assistance); housing and mortgage finance agencies; promotion of home ownership; assistance for repair and renovation of existing homes; and programs to encourage private sector housing production."
} 
the full dataset, compared to $54 \%$ in non-southern cities. As for dwelling units within project area boundaries, 79\% are "substandard" in the city sample. ${ }^{9}$ This aligns closely with the share of residential and non-residential units deemed substandard in the project-level sample.

At approximately the same time that central cities engaged in urban renewal efforts, many were also redeveloping land for highway construction. The city-level average miles of interstates constructed was only 0.6 by 1950 , before the federal government significantly increased its share of subsidies via the 1956 Interstate Highway Act. A decade later, this had increased to 2.9 miles. The measure more than doubled to 6.1 miles by 1970 .

Table 2 describes the level and allocation of local revenues and expenditures by function. The earliest records of local government finances in our sample is 1967, when data was available for almost 600 out of the 713 cities. Coverage improved notably beginning in 1972, with data collected for 685 cities and 706 counties. Average city-level revenues and spending per resident were approximately $\$ 1,500$, while per-capita county area-level finances were more than double this amount. On the revenue side, between $1-2 \%$ of total revenues came in the form of federal government subsidies directed towards housing and community development. Breaking down expenditures by function shows that $2-3 \%$ were spent on housing and community development projects at the city and county-area levels. Police protection comprised a larger share of city-level spending (12\%) relative to county areas (4\%). The same holds for water supply, electric power, and gas supply utilities, which took up $12 \%$ and $6 \%$ of city- and county area-level spending, respectively. K-16 education is by far the largest spending category at the aggregate county area level (47\%) because records include both independent and dependent school districts. In contrast, K-16 city expenditures only account for city-dependent public school systems and therefore represents only $9 \%$ of total expenditures.

\footnotetext{
${ }^{9}$ The precise definition of substandard dwelling is left to local authorities and have been measured by taking into account construction, maintenance, plumbing facilities, sanitary conditions, and overcrowding (Johnstone, 1958).
} 


\section{Research Design}

\subsection{Instrumental Variables Approach}

Our empirical approach is based on the Bartik or shift-share instrument commonly used in the trade and migration literatures (Altonji and Card, 1991; Card, 2001). Boustan (2010) was the first to apply this instrument to the Great Migration context. The fundamental identification challenge is that migrants select into destinations outside of the South based on factors such as local demand conditions. A valid instrument for Black migration inflows into northern cities must not affect local demand conditions and other city-level shocks except via predicted inflows. To construct a valid instrument, we rely on an interaction between historical settlement patterns of Black migrants and so-called "push factors," or local economic conditions in Southern sending cities.

Economic fluctuations in the predominantly agricultural and mining sectors in the rural South are unlikely to be correlated with local demand conditions in the north and west, which rely heavily on manufacturing and services. An economic shock to cotton production in the South, for example via cotton harvesters and related forms of mechanization, can push Black individuals away from origin cities and counties (Grove and Heinicke, 2003; Heinicke and Grove, 2005). In order to ensure that predicted Black migration is not responding to contemporaneous labor market factors in northern cities, we rely on historically persistent migration routes out of the South. These routes were heavily influenced by railroad infrastructure designating origin-destination city pairs that led to long-term community networks. There was substantial variation existing within states and regions (Black et al., 2015). For example, residents of eastern Mississippi on the Mobile and Ohio line were likely to migrate to the northern terminus of St. Louis while residents of western Mississippi along the Illinois Central were more likely to head to Chicago. These migratory routes were well established by the first wave of the Great Migration, prior to World War II.

The combination of historic settlement patterns determined by the placement of railroad lines and exogenous push factors in the South creates changes in Black migration flows that are plausibly orthogonal to local demand conditions in northern and western cities. ${ }^{10}$ This interaction is used to instrument for actual changes in Black population in receiving cities over the same period,

\footnotetext{
${ }^{10}$ In the language of Goldsmith-Pinkham et al. (2020) we assume that the "shares" are exogenous. In our case this reflects the previous share of Black migrants from each Southern county to each city due historical settlement patterns as we describe in greater detail below.
} 
as shown below:

$$
\widehat{m i g_{c}}=\sum_{j}\left(\omega_{c j}^{1935-1940} \cdot \widehat{m i g_{j}}\right)
$$

The predicted migration in receiving city $c$ during $1940-1950, \widehat{m i g}_{c}$, is a function of historical migration patterns from sending county $j$ to city $c$ from 1935 to $1940\left(\omega_{c j}^{1935-1940}\right)$ and predicted migration from the southern county based on economic push factors $\left(\widehat{\mathrm{mig}_{j}}\right)$ during $1940-1950$. Whereas Boustan (2010) relied on cross-state variation in economic shocks to generate predicted migration from sending southern states, this formulation utilizes the complete count 1940 Census to leverage variation in push factors across more than 1,200 counties rather than a limited number of states. This formulation therefore closely follows Derenoncourt (2020) but departs from it in one notable way. Instead of aggregating up to the commuting zone level, we use city-level observations in our analytic sample.

$\omega_{c j}^{1935-1940}$ is computed as the share of Black southern migrants living in city $c$ in 1940 who listed $j$ as their county of residence in 1935. Data comes from the 1940 Census, which asks respondents to report their place of residence in 1935. This permits a comprehensive view of recent Black migration to northern and western cities. Predicted migration in the second component of Equation 1 is based on estimates of net county-level Black migration rates in 1940-1950 as a function of southern economic conditions in $1940\left(\mathbf{P u s h}_{j}\right)$ :

$$
\text { MigRate }_{j}=\gamma+\mathbf{P u s h}_{j}^{\prime} \Gamma+\epsilon_{j}
$$

where MigRate $_{j}$ is calculated as the change in Black population from 1940 to 1950 in county $j$ divided by the Black population in county $j$ in 1940. To determine the contents of Push , we $_{j}$ begin with the nine economics conditions outlined in Boustan (2010) and select a subset using a Post-LASSO estimation procedure to improve its predictive power. ${ }^{11}$ The eight variables included in the vector of push factors are the percent acreage planted in cotton, share of farmers as tenants, WWII spending per capita, share of the labor force in agriculture, the interaction between a tobacco growing state and share in agriculture, share of the labor force in mining, being in a mining state,

\footnotetext{
${ }^{11}$ This approach follows Derenoncourt (2020).
} 
and the interaction between the share of the labor force in mining and being in a mining state. Source data for these economic factors are all taken from the City and County Data Book, with the exception of cotton acreage which comes from the National Agricultural Statistical Service, Censuses of Agriculture, and the ICPSR project on Population and Environment in the U.S. Great Plains. The predicted level of county-level Black migration $\left(\widehat{\mathrm{mig}_{j}}\right)$ is calculated by multiplying the Black population in county $\mathrm{j}$ in 1940 by the predicted net Black migration rate $\left(\right.$ MigRate $\left._{j}\right)$ from estimating Equation (2). $\widehat{m i g}_{j}$ is then used as an input into computing city-level predicted net migration $\left(\widehat{\mathrm{mig}_{c}}\right)$ in Equation (1). On average, cities in our sample received 558 Black migrants between 1940-1950, with a standard deviation of 5,140.

\subsection{Empirical Specification}

We are interested in estimating the causal effect of Black migration on city-level outcomes. The first stage relationship between actual Black population change in receiving cities and the instrument of predicted Black migration in 1940-1950 is expressed by the following equation.

$$
A c t M i g_{c}=\lambda+\widehat{\rho m i g_{c}}+\mathbf{x}_{c}^{\prime} \Theta+\varepsilon_{c}
$$

Actual migration and the instrument of predicted migration are both expressed in percentiles. The choice of functional form is informed by the heavily right-skewed distribution of changes in the Black population. $\mathbf{x}_{c}^{\prime}$ denotes a vector of covariates including the destination city's population in 1940, its share of the labor force in manufacturing, and state fixed effects. We account for the prevalence of manufacturing jobs in destination cities since many Black migrants were attracted to economic opportunities in the industrialized North. Even though the instrument only relies on agricultural and mining push factors in the South instead of manufacturing pull factors, controlling for the baseline prevalence of manufacturing jobs provides further assurance that local governments' responses to new Black arrivals are not influenced by variation in local economic conditions. The addition of state fixed effects absorbs time-invariant state characteristics that may be associated with the propensity to undertake urban renewal projects and related spatial policies. The analogous reduced form equation is as follows: 


$$
Y_{c}=\alpha+\widehat{\beta m i g_{c}}+\mathbf{x}_{c}^{\prime} \Omega+\epsilon_{c}
$$

For ease of interpretation, we re-scale the instrument so that $\beta$ is the effect of a 10-percentile point increase in predicted Black net migration on city-level outcomes. Causal inference is plausible so long as the instrument, conditional on baseline covariates, affects cities' spatial policies only through predicted migration inflows and not local labor demand factors or related shocks. Identification rests on the orthogonality between the shift-share instrument and the unobserved residual. Reliance on a smaller administrative unit, such as county, is advantageous because it creates shocks for hundreds of origin locations that are plausibly unrelated to shocks in destination cities. While we cannot test directly for this orthogonality, we undertake additional analyses to assess the robustness of our findings, including examining whether we observe similar results from White in-migration.

\section{Results}

\subsection{First Stage}

Table 3 confirms a strong correlation between actual and predicted Black migration. The reported coefficient corresponds to $\rho$ from the first stage equation regressing the percentile of actual Black population change in receiving cities from 1940-1950 on the percentile of predicted migration over the same period and a set of baseline characteristics.

A 10-percentile point increase in predicted Black migration is associated with a 3.6 percentile point increase in actual migration from 1940 to $1950 .{ }^{12}$ The coefficient is highly significant, with a Kleibergen-Paap F-statistic of over 95. Figure 3 provides a visual representation of this relationship between predicted and actual Black inflows residualized on the set of covariates. It reveals no apparent outliers, such that the relationship is robust to omitting particular cities from the sample.

\footnotetext{
${ }^{12}$ Note that two dozen cities are omitted from this analysis due to missing data on Black populations in 1950.
} 


\subsection{Effects of Black Migration on Urban Renewal}

Table 4 shows both reduced form and two-stage least squares (2SLS) estimates of the effect of Black migration on cities' urban renewal activities. We examine both the margin of participation whether cities have at least one urban renewal project - and the extent of federal grants approved. The top row of Table 4 shows estimates of $\beta$, or the effect on city-level outcomes of a 10-percentile point increase in predicted Black migration from 1940-1950. The bottom row presents 2SLS estimates of the effect of a 10-percentile point increase in actual Black migration on receiving cities' urban renewal efforts.

A 10-percentile rise in predicted Black migrants increases the likelihood of the city having at least one urban renewal project by 3.7 percentage points. Cities experiencing an analogous increase in actual Black migration are 10 percentage points more likely to have undertaken at least one urban renewal project during the study period. Relative to a baseline participation rate of $67 \%$, this translates to an increase of nearly $15 \%$. The heightened clearance of urban areas do not appear to be concentrated in time. Figure 4 shows that Black migration induced similar numbers of urban renewal projects between 1955-1974. A 10-percentile point increase in actual Black migration induced between 0.2-0.3 additional urban renewal projects in each of the four 5-year bins, for a total of approximately one additional project over the two-decade period. The remainder of Table 4 focuses on the amount of federal grants approved for urban renewal projects. A 10-percentile point increase in actual Black migration led to the approval of an additional \$39 per capita in federal grant money.

Having established that Black migration appears to increase a city's likelihood of undertaking an urban renewal project, we now turn to examining the nature and scope of these efforts and their consequences. Table 5 focuses on three dimensions: estimated family displacement, types of dwelling units targeted for clearance, and the size and proposed reuse of project land. Columns 1 and 2 show that a 10-percentile point increase in Black migration leads to the estimated displacement of 39 additional White households and 89 additional non-White households. Given the size

of standard errors, we cannot rule out that these effects are statistically equivalent. To put these effect sizes in context, moving from the 10th percentile in terms of actual Black migration to the 90th percentile would yield the planned displacement of an additional 310 White families and 
over 710 non-White families. Next we separately consider the the effects on types of dwellings that cities propose to demolish. Greater Black migration increases the planned clearance of both substandard and standard dwellings by 92 and 53 units, respectively. The corresponding rise in total land area slotted for urban renewal projects is 2.4 acres. Greater Black in-migration from the South increases the amount of land redeveloped for residential purposes by 0.8 acres, with the remainder directed towards commercial, industrial, public, and rights-of-way purposes. ${ }^{13}$

The evidence suggests that Black in-migration led to expansions in the amount of land cleared under the urban renewal program, with only a fraction reserved for dwelling and related residential use. This prompts the question of whether the Great Migration might contribute to fewer dwelling units, as previously residential neighborhoods are converted to industrial or commercial use. We use supplementary data on city-level dwelling characteristics during 1950 and 1960 from the County and City Data Book to examine the effect of Black migration on the number and attributes of homes. Appendix Table A3 shows that a 10-percentile point increase in Black migrants decreased the number of dwelling units by over 1,800. This coefficient is measured with considerable noise, and its magnitude may partially be explained by data availability among only the 311 largest cities. While the coefficients on the share of homes with detached structures and hot running water and private bath are negative, they are not statistically significant.

\subsection{Effects on Highway Construction}

The rise in urban renewal participation in response to Black in-migration raises the question of whether similar effects are apparent when examining interstate construction over the same period. Reduced residential demand in central cities as a result of the Great Migration led to White outmigration into the suburbs, a process facilitated by the construction of interstates (Baum-Snow, 2007; Boustan, 2010). The arrival of Black migrants may thus accelerate or expand highway construction within central cities, in particular through Black neighborhoods that disproportionately bear the burden of such construction (Rose and Mohl, 2012).

Since our analysis of Great Migration inflows is at the city-level rather than the neighborhood level we lack the granularity to determine how Black neighborhoods may have been affected by

\footnotetext{
${ }^{13}$ The effects on acres of land cleared for commercial, industrial, public, and rights-of-way purposes are available in Appendix Table A2.
} 
highway construction. Instead, we look at city-level measures of highway construction. Specifically, in Table 6 we report effects based on city-level data on miles of interstate highways built. We find that increased Black in-migration does not significantly affect total highway mileage within

city boundaries. Notably, coefficients are positive when examining cumulative miles by 1960 and beyond, but standard errors are sufficiently large to preclude us from rejecting the null of no effect at conventional levels. ${ }^{14}$ While we can rule out sizable changes in aggregate cumulative miles of highways built in a city, these results cannot address whether there were changes in highway placement within a city in response to Black in-migration. Therefore, we cannot directly examine whether Black neighborhoods were more prone to land clearance for interstate construction.

\subsection{Effects on Local Government Finance}

Table 7 shows reduced form and 2SLS estimates of the effect of Black migration on local government revenues and expenditures in the area of housing and community development. We begin with dependent variables on intergovernmental revenue from the federal government, before examining expenditures in housing and community development at both city and county area levels. ${ }^{15}$ For each outcome we show estimates at 5-year intervals from 1967 to 1987. The preponderance of local governments are covered in the historical Census finance datasets beginning in 1972 (e.g. 698 cities have corresponding county area information), but city-level data in 1967 still lags with records for 592 out of 713 cities.

Per capita revenue from the federal government for housing and community development increases with greater Black migration into northern and western cities. According to Table 7, a 10-percentile point increase in actual Black migration raises per-capita revenues at the city-level by \$10 in 1967 and \$20 in 1972. Corresponding changes in expenditures at the city-level are of similar magnitudes. Notably, increases in city-level revenues and spending tend to peak in the earlier years of 1967 and 1972 and taper off by the late 1980s. For example, increased Black migration only increases city-level revenues from federal sources by $\$ 6$ per capita in 1987, a significant decrease from the 1972 peak of $\$ 20$.

To place the magnitude of revenue increases from the federal government in context, the coef-

\footnotetext{
${ }^{14}$ For example, the p-value corresponding to the 2SLS estimate for miles of highway constructed by 1960 is 0.109.

${ }^{15}$ Note that all outcomes are expressed in dollars per capita (2017 dollars).
} 
ficient of \$20 per capita for 1972 is similar to the effect of a 10-percentile point increase in actual Black migration on per capita federal grants disbursed for the purposes of local urban renewal efforts. The latter, however, refers to the total amount at the city-level over the study period, while Table 7 estimates only pertain to a given year. Since the housing and community development functional area includes federal funding for an expansive set of projects such as public housing construction and operation, rent subsidy programs, and community development projects including urban renewal, these results suggest that the consequences of greater Black migration may be substantially more expansive than urban renewal efforts alone.

Finally, Table 7 shows the corresponding impacts on county-level revenues and expenditures. 2SLS estimates show an increase of between \$4-7 per capita on county-level revenues, with the effects smaller in earlier years (e.g. 1972) than at the city-level. Unlike city-level outcomes, there do not appear to be any tapering off in the magnitudes of effects over time.

While our focus is on local governmental responses in the form of housing and community development, the arrival of Black migrants may have induced changes in other functional areas. Table A4 shows that higher Black migration results in greater spending on police protection, consistent with findings in the literature (e.g. Derenoncourt (2020)). Between 1972-1987, a 10-percentile point increase in Black migration led to additional \$11-15 per person in city-level police-related expenditures, or nearly $10 \%$ of baseline spending. The relative increase is similar in magnitude when expanding the unit of local government to the county area.

Tables A5 and A6 show corresponding effects for utilities and K-16 education. Increased Black migration reduces per-capita spending on utility spending spanning water supply, electric power, and gas supply at the city-level, but does not affect utility expenditures at the county area level. In contrast, education spending across all levels of local government increases as a result of greater Black migration into receiving cities.

\subsection{Robustness and Placebo Checks}

To ensure that our estimates capture the causal effect of Black in-migration on city-level outcomes, we undertake a number of placebo and robustness tests. First, we examine whether cities' responses are specific to the arrival of Black migrants, since White southerners were also moving 
to these same destinations. Table A7 shows the relationship between actual White in-migration during 1940-1950 and cities' participation in any urban renewal activity, as well as planned family displacement and clearance of structures and land. The coefficients on southern White migration convey no relationship between any of these variables after adjusting for actual Black migration during the same period, the 1940 city population, the share of the labor force in manufacturing, and state fixed effects. ${ }^{16}$ This exercise indicates that our main results are particular to the inmigration of Black individuals, and do not capture the consequences of Southern arrivals more generally.

Another potential confounder is historical European migration into cities in our sample. Industrial northern cities experienced a negative shock to European immigrant labor supply stemming from the onset of World War I and changes to U.S. immigration policy in the 1920s (Thomas, 1973). They increasingly turned to Black workers from the South to meet the rising demand for industrial production (Collins, 2020). As such, cities with higher numbers of Black arrivals may share attributes, namely reliance on European immigrant labor and extent of industrialization, that affect their policies toward urban redevelopment. Our instrument specifically addresses such concerns by using variation in Southern push factors that are orthogonal to receiving cities' economic conditions. We furthermore include manufacturing intensity in all of our specifications. Table A8 goes one step further by directly accounting for the role of European migration on our results. We use an instrument for county-level European immigrant labor based on historical access to railroad lines and cross-temporal variation in immigration volumes as described in Sequeira et al. (2020). Our findings on the effect of Black migration do not change after conditioning on this predicted variation in European immigration. Taken together, these results show a minimal role of historical European migration in explaining the consequences of Black in-migration on urban renewal activity.

\section{Conclusion}

The internal migration of millions of African Americans to urban areas outside of the south in search of better opportunities marks a massive demographic shift with lasting consequences. De-

\footnotetext{
${ }^{16}$ White in-migration data at the city-level comes from Derenoncourt (2020), who similarly find no effect of White southern in-migration on her outcome of interest: Black men's upward mobility.
} 
spite substantial economic gains among participants of the Great Migration, research also document that Black migrants suffered negative health consequences and Black children growing up in receiving cities decades later, experienced reduced upward mobility (Black et al., 2015; Derenoncourt, 2020). Evidence suggests that responses from local governments culminated in a deterioration in the quality of the urban environment. However, research is still limited on the nature of these responses, especially in the ways they manifest in cities' urban spatial policies.

This paper examines the effect of the Great Migration on receiving cities' urban renewal efforts. This ambitious federally-subsidized and locally planned program involved the large-scale assembly and redevelopment of land in central cities. We show that in response to the arrival of Black migrants in the middle of the twentieth century, cities in the north and west were more likely to undertake urban renewal projects and redevelop areas of "urban blight." We find that a rise in Black migration significantly increased the estimated number of displaced families and demolition of both substandard and standard structures.

A closer review of local public expenditures reveals that higher spending on housing and community development projects, including urban renewal projects, are accompanied by lower expenditures on public utilities and higher police spending. Taken together, our results suggest that the redevelopment and rehabilitation of central cities is a potential mechanism that can illuminate the adverse long-term health or intergenerational impacts of the Great Migration previously documented in the literature. Cities were not passive recipients of new Black arrivals, and responded systematically by reconstructing urban spaces in ways that altered the quality of these communities. Future work will investigate the lasting consequences of these spatial policies on Black individuals and neighborhoods. 


\section{References}

Daniel Aaronson and Bhashkar Mazumder. The Impact of Rosenwald Schools on Black Achievement. Journal of Political Economy, 119(5):821-888, October 2011.

Joseph G. Altonji and David Card. The Effects of Immigration on the Labor Market Outcomes of Less-skilled Natives. Immigration, Trade, and the Labor Market, pages 201-234, January 1991. Publisher: University of Chicago Press.

Francesca Russello Ammon. Bulldozer: Demolition and Clearance of the Postwar Landscape. Yale University Press, January 2016.

Martin Anderson. The Federal Bulldozer: A Critical Analysis of Urban Renewal, 1949-1962. McGrawHill, 1967.

Cavit Baran, Eric Chyn, and Bryan A Stuart. The Great Migration and Educational Opportunity. page 79, 2020.

Nathaniel Baum-Snow. Did Highways Cause Suburbanization?*. The Quarterly Journal of Economics, 122(2):775-805, May 2007.

Dan A. Black, Seth G. Sanders, Evan J. Taylor, and Lowell J. Taylor. The Impact of the Great Migration on Mortality of African Americans: Evidence from the Deep South. American Economic Review, 105(2):477-503, February 2015.

Leah Platt Boustan. Was Postwar Suburbanization "White Flight"? Evidence from the Black Migration. Quarterly Journal of Economics, 125(1):417-443, February 2010.

Leah Platt Boustan. Competition in the Promised Land: Black Migrants in Northern Cities and Labor Markets. Princeton University Press, 2017.

David Card. Immigrant Inflows, Native Outflows, and the Local Labor Market Impacts of Higher Immigration. Journal of Labor Economics, 19(1):22-64, 2001.

Raj Chetty and Nathaniel Hendren. The Impacts of Neighborhoods on Intergenerational Mobility I: Childhood Exposure Effects. The Quarterly Journal of Economics, 133(3):1107-1162, August 2018a.

Raj Chetty and Nathaniel Hendren. The Impacts of Neighborhoods on Intergenerational Mobility II: County-Level Estimates. The Quarterly Journal of Economics, 133(3):1163-1228, August 2018b.

William J. Collins. The Great Migration of Black Americans from the US South: A Guide and Interpretation. Technical Report w27268, National Bureau of Economic Research, June 2020.

William J Collins and Katharine L Shester. Slum Clearance and Urban Renewal in the United States. American Economic Journal: Applied Economics, 5(1):239-273, 2013.

William J. Collins and Marianne H. Wanamaker. Selection and Economic Gains in the Great Migration of African Americans: New Evidence from Linked Census Data. American Economic Journal: Applied Economics, 6(1):220-252, January 2014.

Ellora Derenoncourt. Can you move to opportunity? Evidence from the Great Migration. pages 1-123, 2020. 
Katherine Eriksson. Moving North and into jail? The great migration and black incarceration. Journal of Economic Behavior E Organization, 159:526-538, March 2019.

Robert M. Fogelson. Downtown: Its Rise and Fall, 1880-1950. Yale University Press, January 2001.

M. T. Fullilove. Root shock: the consequences of African American dispossession. Journal of Urban Health: Bulletin of the New York Academy of Medicine, 78(1):72-80, March 2001.

Mark I. Gelfand. A Nation of Cities: The Federal Government and Urban America, 1933-1965. Oxford University Press, 1975.

Paul Goldsmith-Pinkham, Isaac Sorkin, and Henry Swift. Bartik Instruments: What, When, Why, and How. American Economic Review, 110(8):2586-2624, August 2020.

Wayne A. Grove and Craig Heinicke. Better Opportunities or Worse? The Demise of Cotton Harvest Labor, 1949-1964. The Journal of Economic History, 63(3):736-767, 2003. Publisher: Cambridge University Press.

Craig Heinicke and Wayne A. Grove. Labor Markets, Regional Diversity, and Cotton Harvest Mechanization in the Post-World War II United States. Social Science History, 29(2):269-297, 2005. Publisher: Cambridge University Press.

Arnold R. Hirsch. Searching for a "Sound Negro Policy": A Racial Agenda for the Housing Acts of 1949 and 1954. Housing Policy Debate, 11(2):393-441, January 2000.

Alexander von Hoffman. A study in contradictions: The origins and legacy of the housing act of 1949. Housing Policy Debate, 11(2):299-326, January 2000.

Quintin Johnstone. The Federal Urban Renewal Program. The University of Chicago Law Review, 25 (2):301-354, 1958.

Jessica LaVoice. The Long-Run Implications of Slum Clearance: A Neighborhood Analysis. Working paper, page 72, 2019.

National Commission on Urban Problems. Building the American city: report of the National Commission on Urban Problems to the Congress and to the President of the United States., 1969.

US Department of Housing and Urban Development. Urban Renewal Project Characteristics, June 30, 1966. Technical report, US Department of Housing and Urban Development, Washington, D.C., 1967.

Mark H Rose and Raymond A Mohl. Interstate: Express Highway Politics, 1939-2009. University of Tennessee Press, Chicago, 2012.

Sandra Sequeira, Nathan Nunn, and Nancy Qian. Immigrants and the Making of America. Review of Economic Studies, 87(1):382-419, 2020.

Bryan A. Stuart and Evan J. Taylor. The Effect of Social Connectedness on Crime: Evidence from the Great Migration. The Review of Economics and Statistics, pages 1-46, August 2019.

Jon C. Teaford. Urban Renewal and Its Aftermath. Housing Policy Debate, 11(2):443-465, January 2000. 
Brinley Thomas. Migration and Economic Growth: A Study of Great Britain and the Atlantic Economy. Cambridge University Press, Cambridge Eng., 2nd edition edition, May 1973.

Alexander von Hoffman. A study in contradictions: The origins and legacy of the housing act of 1949. Housing Policy Debate, 11(2):299-326, January 2000.

James Q. Wilson. Urban Renewal: The Record and the Controversy. M.I.T. Press, 1966. 
Figure 1: Total Black Southern Migrant Population, 1935-1940 (in Thousands)

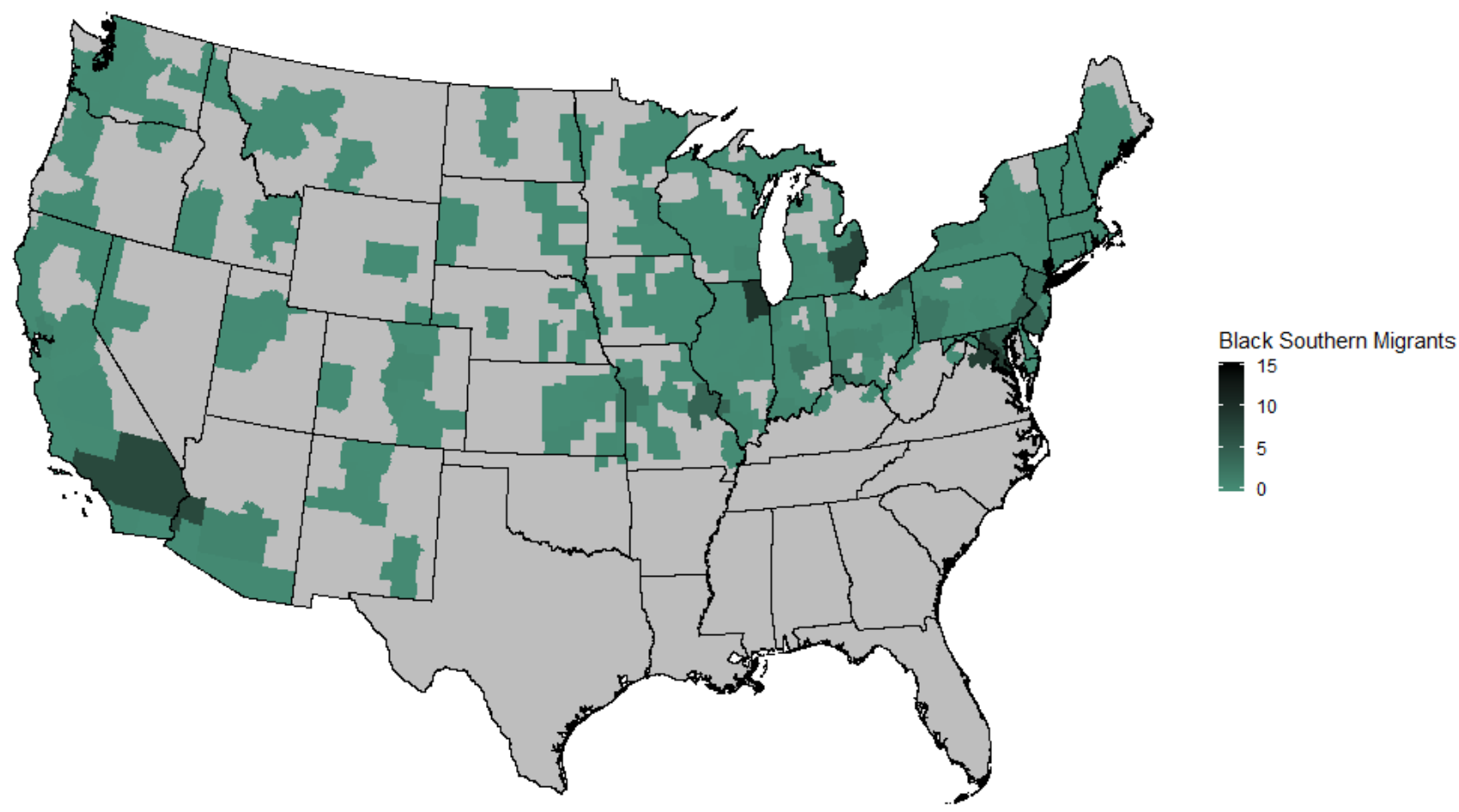

Notes: Map aggregates city-level observations to the commuting zone level. Black southern migrant population data relies on the 1940 Census, which identifies the number of black migrants who moved from a southern place of residence in 1935 to a non-southern residence by 1940 . 
Figure 2: Total Number of Urban Renewal Projects

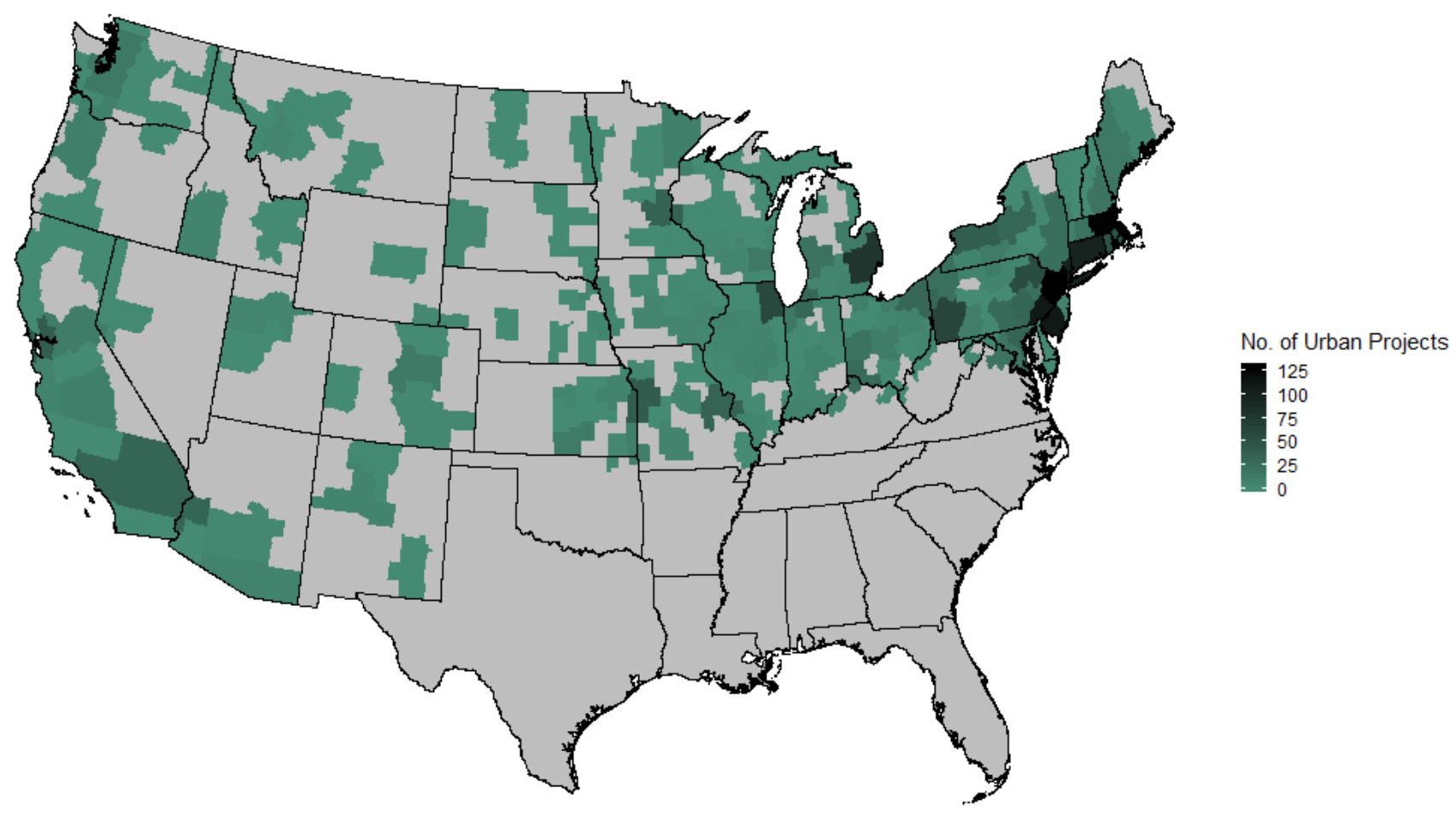

Notes: Map aggregates city-level observations to the commuting zone level. 
Figure 3: First Stage

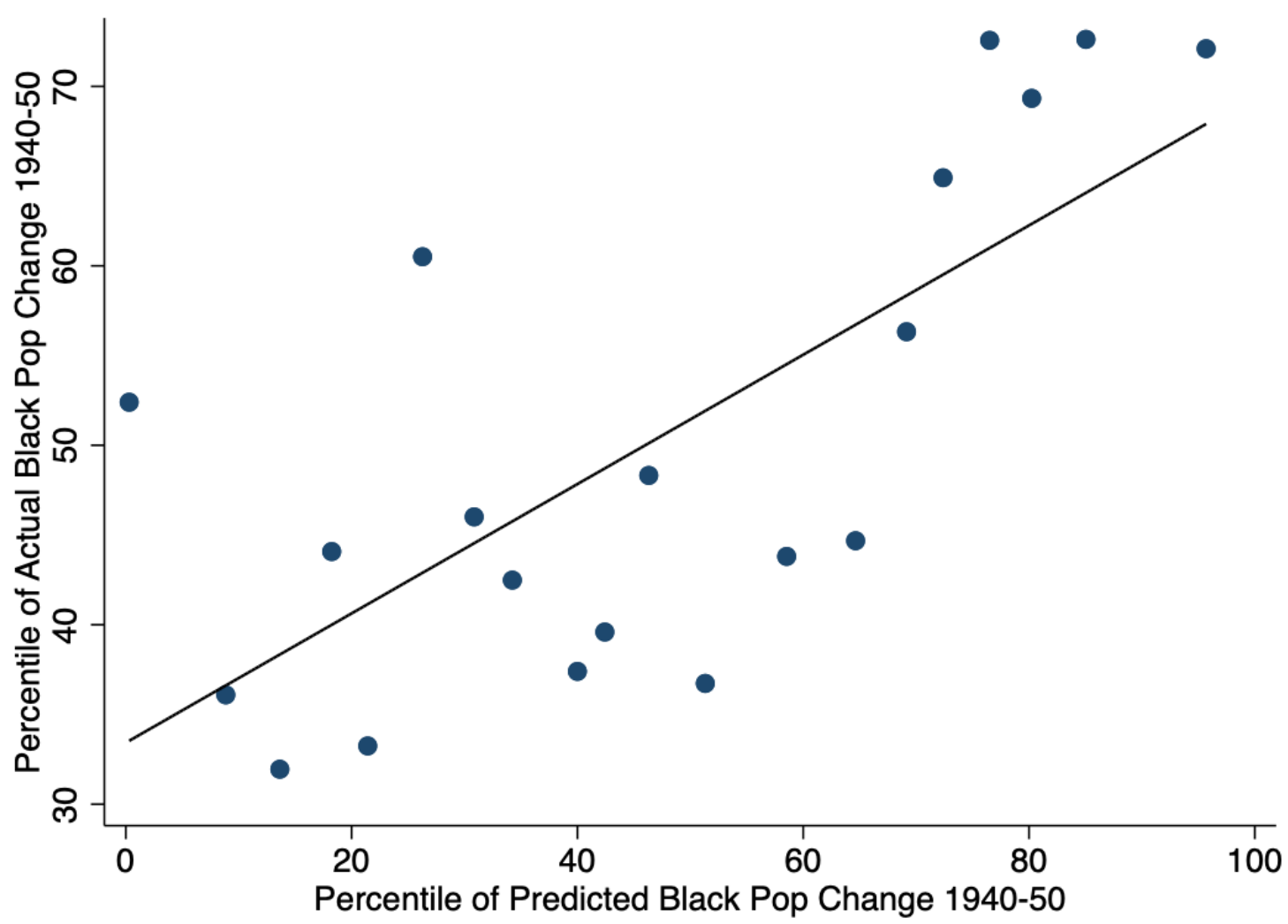

Notes: The graph shows the relationship between the residualized Black population change during 1940-1950 and residualized actual Black population change, after controlling for the 1940 population of the receiving city, the share of the labor force in manufacturing, and state fixed effects. The scatterplot then groups the residualized instrument into 20 equal-sized bins. All data is at the city level. 
Figure 4: Effect on No. of Urban Renewal Projects over Time

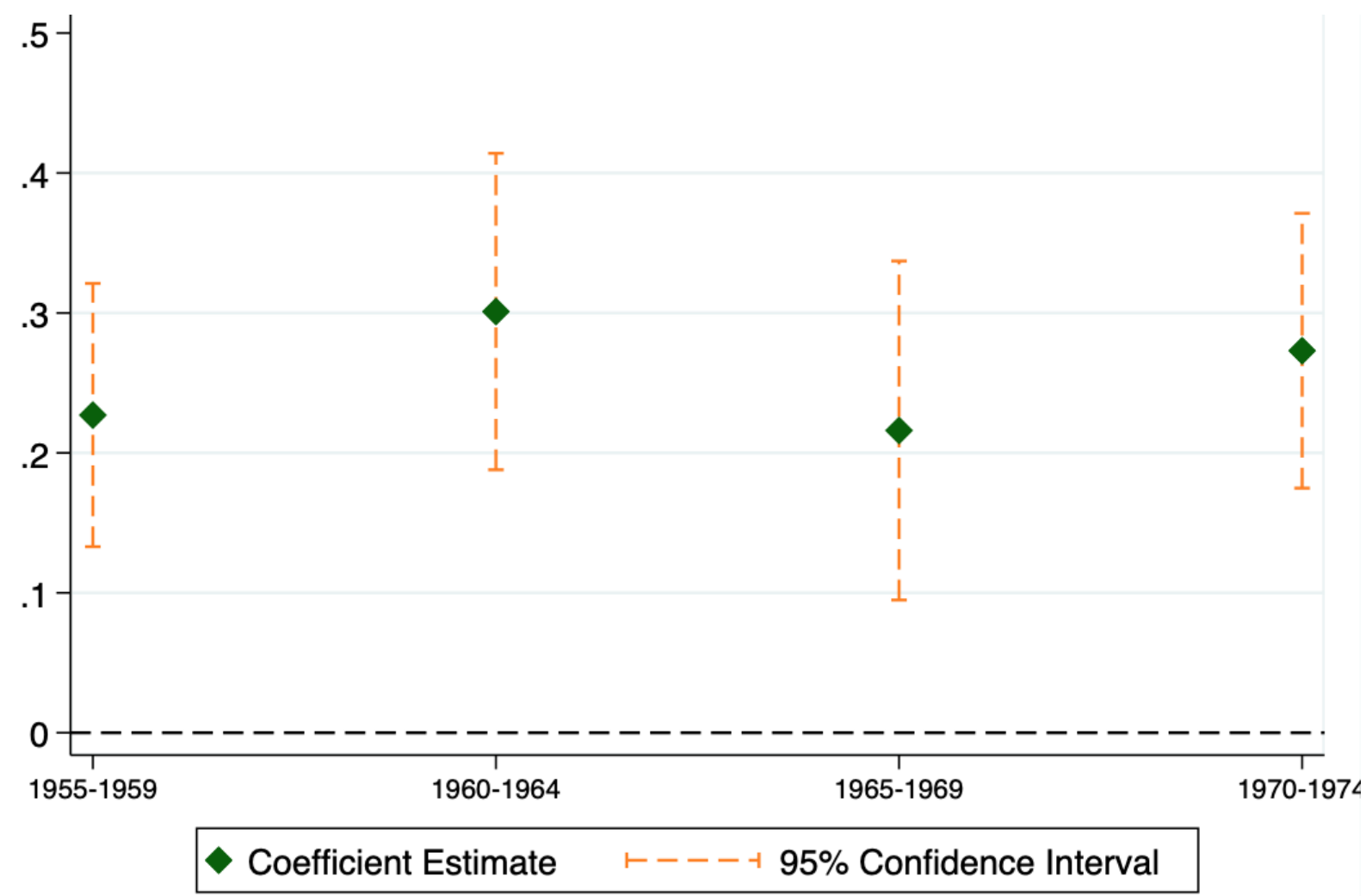

Notes: Graph reports 2SLS estimates of the effect of a 10-percentile point increase in actual Black population on the number of urban renewal projects. The instrument is the percentile of predicted Black population increase in 1940-1950, defined as the interaction between pre-1940 Black southern migration patterns and post-1940 outflows of migrants as predicted by southern economic factors alone. All specifications include the 1940 population of the receiving city, the share of the labor force in manufacturing, and state fixed effects. Standard errors are clustered at the city level. 
Table 1: Summary Statistics

\begin{tabular}{lccc}
\hline & Mean & Std. Dev. & $\mathrm{N}$ \\
\hline City population: 1940 & 71766 & 336161 & 713 \\
Actual Black population increase, 1940-1950 & 2720 & 17493 & 687 \\
At least one UR project & .67 & .47 & 713 \\
& & & \\
City-level characteristics, cond. on at least one UR project: & & & \\
No. of UR projects & 4.6 & 6.3 & 481 \\
No. of UR projects, 1955-1959 & .95 & 2.4 & 481 \\
No. of UR projects, 1960-1964 & 1.1 & 1.8 & 481 \\
No. of UR projects, 1965-1969 & 1.4 & 2.1 & 481 \\
No. of UR projects, 1970-1974 & 1.1 & 1.3 & 481 \\
Federal grants approved for city, per capita & 301 & 323 & 481 \\
Federal grants disbursed for city, per capita & 159 & 177 & 481 \\
Estimated displacement: No. of White families & 250 & 992 & 481 \\
Estimated displacement: No. of non-White families & 253 & 1208 & 481 \\
Estimated clearance: No. of substandard dwelling units & 579 & 2522 & 481 \\
Estimated clearance: No. of standard dwelling units & 153 & 627 & 481 \\
Project land total acres & 7 & 21 & 481 \\
Project land acres for residential use & 2.3 & 7.9 & 481 \\
& & & \\
Interstate construction: & & & 713 \\
Miles built in city by 1950 & 0.6 & 4.1 & 713 \\
Miles built in city by 1960 & 2.9 & 9.2 & 713 \\
Miles built in city by 1970 & 6.1 & 17 & \\
\hline
\end{tabular}

Notes: The sample consists of 713 city-level observations. Per capita federal grants are calculated as the total sum approved or disbursed divided by the 1940 city population. ${ }^{* * *} \mathrm{p}<0.01,{ }^{* *} \mathrm{p}<0.05,{ }^{*} \mathrm{p}<0.1$ 
Table 2: Summary Statistics - Local Public Finance

\begin{tabular}{|c|c|c|c|c|}
\hline & \multicolumn{2}{|c|}{ City-Level Finances: } & \multicolumn{2}{|c|}{ County-Level Finances: } \\
\hline & Mean & Std. Dev. & Mean & Std. Dev. \\
\hline \multicolumn{5}{|l|}{ Revenues in 1972} \\
\hline Total revenue, per capita & 1465 & 875 & 3107 & 994 \\
\hline \multicolumn{5}{|l|}{ Share of total revenues: } \\
\hline Revenue from fed gov't for housing/comm. dev. & 0.02 & 0.05 & 0.01 & 0.02 \\
\hline \multicolumn{5}{|l|}{ Expenditures in 1972} \\
\hline Total expenditure, per capita & 1508 & 962 & 3191 & 1085 \\
\hline \multicolumn{5}{|l|}{ Share of total expenditures: } \\
\hline Housing/community development expenditures & 0.03 & 0.06 & 0.02 & 0.03 \\
\hline Police protection & 0.12 & 0.07 & 0.04 & 0.02 \\
\hline Utilities & 0.13 & 0.15 & 0.06 & 0.06 \\
\hline Education & 0.09 & 0.19 & 0.47 & 0.10 \\
\hline
\end{tabular}

Notes: The sample consists of 685 city-level observations and 706 county-level observations. All amounts are expressed in constant 2017 dollars. ${ }^{* * *} \mathrm{p}<0.01,{ }^{* *} \mathrm{p}<0.05,{ }^{*} \mathrm{p}<0.1$ 
Table 3: First Stage - Effect of Predicted Black Migration on Actual Migration

Actual Black Population Increase During 1940-1950, Percentile

Instrument:

(1)

Predicted Black Migration, Percentile

$0.360^{* * *}$

(0.037)

Observations

686

F-Statistic

95.26

Notes: The table shows the relationship between the percentile of actual Black population increase in receiving cities and the instrument for Black population increase during 1940-1950. The instrument is the percentile of predicted Black population increase in 1940-1950, defined as the interaction between pre-1940 Black southern migration patterns and post-1940 outflows of migrants as predicted by southern economic factors alone. The specification also includes the 1940 population of the receiving city, the share of the labor force in manufacturing, and state fixed effects. The sample excludes cities with missing data on 1950 Black populations. Standard errors are clustered at the city level. ${ }^{* * *} \mathrm{p}<0.01,{ }^{* *} \mathrm{p}<0.05,{ }^{*} \mathrm{p}<0.1$. 
Table 4: Effect of Black Migration on Urban Renewal Participation

\begin{tabular}{lcc}
\hline & \multicolumn{2}{c}{ Dependent variables: } \\
\cline { 2 - 3 } & $\begin{array}{c}\text { At Least One } \\
\text { UR Project } \\
(1)\end{array}$ & $\begin{array}{c}\text { Per Capita } \\
\text { Grant Approved } \\
(2)\end{array}$ \\
\hline Reduced Form & & $14.94^{* * *}$ \\
Predicted Black Migration (10 Perc.) & $\begin{array}{c}0.0365^{* * *} \\
(0.00568)\end{array}$ & $(3.982)$ \\
Observations & 705 & 705 \\
2SLS & & \\
Actual Black Migration (10 Perc.) & $0.0989^{* * *}$ & $38.94^{* * *}$ \\
& $(0.0147)$ & $(10.90)$ \\
Observations & 682 & 682 \\
\hline
\end{tabular}

Notes: Reduced form estimates are the effect of predicted Black migration on urban renewal outcomes. The instrument is the percentile of predicted Black population increase in 1940-1950, defined as the interaction between pre-1940 Black southern migration patterns and post-1940 outflows of migrants as predicted by southern economic factors alone. Coefficients should be interpreted as the effect of a 10-percentile point increase in predicted Black migration. The 2SLS estimates are the effect of a 10-percentile point increase in actual Black population on urban renewal outcomes. All specifications include the 1940 population of the receiving city, the share of the labor force in manufacturing, and state fixed effects. Standard errors are clustered at the city level. ${ }^{* * *} \mathrm{p}<0.01,{ }^{* *} \mathrm{p}<0.05,{ }^{*} \mathrm{p}<0.1$. 
Table 5: Effect of Black Migration on Urban Renewal Characteristics

\begin{tabular}{|c|c|c|c|c|c|c|}
\hline & \multicolumn{2}{|c|}{ Family Displacement: } & \multicolumn{2}{|c|}{ Dwelling Unit Clearance: } & \multicolumn{2}{|c|}{ Project Land Acreage: } \\
\hline & $\begin{array}{l}\text { White } \\
\text { (1) }\end{array}$ & $\begin{array}{l}\text { Non-White } \\
\text { (2) }\end{array}$ & $\begin{array}{l}\text { Substandard } \\
\text { (3) }\end{array}$ & $\begin{array}{l}\text { Standard } \\
(4)\end{array}$ & $\begin{array}{c}\text { Total } \\
(5)\end{array}$ & $\begin{array}{l}\text { Residential } \\
\text { (6) }\end{array}$ \\
\hline \multicolumn{7}{|l|}{ Reduced Form } \\
\hline Predicted Black Migration (10 Perc.) & $\begin{array}{l}14.40^{* *} \\
(6.015)\end{array}$ & $\begin{array}{c}31.64^{* * *} \\
(10.46)\end{array}$ & $\begin{array}{c}33.21^{* *} \\
(13.05)\end{array}$ & $\begin{array}{c}19.12^{* * *} \\
(7.039)\end{array}$ & $\begin{array}{c}0.868^{* * *} \\
(0.229)\end{array}$ & $\begin{array}{c}0.296^{* * *} \\
(0.0923)\end{array}$ \\
\hline Observations & 705 & 705 & 705 & 705 & 705 & 705 \\
\hline \multicolumn{7}{|l|}{$2 S L S$} \\
\hline Actual Black Migration (10 Perc.) & $\begin{array}{l}38.91^{* *} \\
(16.38)\end{array}$ & $\begin{array}{c}88.71^{* * * *} \\
(28.96)\end{array}$ & $\begin{array}{l}91.73^{* *} \\
(35.91)\end{array}$ & $\begin{array}{c}52.68^{* * *} \\
(18.73)\end{array}$ & $\begin{array}{c}2.380^{* * * *} \\
(0.606)\end{array}$ & $\begin{array}{c}0.817^{* * *} \\
(0.250)\end{array}$ \\
\hline Observations & 682 & 682 & 682 & 682 & 682 & 682 \\
\hline
\end{tabular}

Notes: Reduced form estimates are the effect of predicted Black migration on urban renewal outcomes. The instrument is the percentile of predicted Black population increase in 1940-1950, defined as the interaction between pre-1940 Black southern migration patterns and post-1940 outflows of migrants as predicted by southern economic factors alone. Coefficients should be interpreted as the effect of a 10-percentile point increase in predicted Black migration. The 2SLS estimates are the effect of a 10-percentile point increase in actual Black population on urban renewal outcomes. All specifications include the 1940 population of the receiving city, the share of the labor force in manufacturing, and state fixed effects. Standard errors are clustered at the city level. ${ }^{* * *} \mathrm{p}<0.01,{ }^{* *}$ $\mathrm{p}<0.05,{ }^{*} \mathrm{p}<0.1$. 
Table 6: Effects of Black Migration on Highway Construction

\begin{tabular}{|c|c|c|c|c|c|}
\hline & \multicolumn{5}{|c|}{ Miles of Highway Constructed in City by: } \\
\hline & $\begin{array}{c}1940 \\
(1)\end{array}$ & $\begin{array}{c}1950 \\
(2)\end{array}$ & $\begin{array}{c}1960 \\
(3)\end{array}$ & $\begin{array}{c}1970 \\
(4)\end{array}$ & $\begin{array}{c}1980 \\
(5)\end{array}$ \\
\hline \multicolumn{6}{|l|}{ Reduced Form } \\
\hline Predicted Black Migration (10 Perc.) & $\begin{array}{r}-0.00255 \\
(0.0721)\end{array}$ & $\begin{array}{l}-0.0105 \\
(0.0726)\end{array}$ & $\begin{array}{c}0.183 \\
(0.119)\end{array}$ & $\begin{array}{c}0.290 \\
(0.236)\end{array}$ & $\begin{array}{c}0.443 \\
(0.305)\end{array}$ \\
\hline Observations & 705 & 705 & 705 & 705 & 705 \\
\hline \multicolumn{6}{|l|}{$2 S L S$} \\
\hline Actual Black Migration (10 Perc.) & $\begin{array}{r}-0.0137 \\
(0.200)\end{array}$ & $\begin{array}{r}-0.0365 \\
(0.201)\end{array}$ & $\begin{array}{c}0.510 \\
(0.318)\end{array}$ & $\begin{array}{c}0.783 \\
(0.634)\end{array}$ & $\begin{array}{c}1.204 \\
(0.814)\end{array}$ \\
\hline Observations & 682 & 682 & 682 & 682 & 682 \\
\hline
\end{tabular}

Notes: Highway outcomes are defined at the city-level across 10-year intervals. Reduced form estimates are the effect of predicted Black migration on the miles of highway constructed within the city boundary. The instrument is the percentile of predicted Black population increase in 1940-1950. Coefficients should be interpreted as the effect of a 10-percentile point increase in predicted Black migration. The 2SLS estimates are the effect of a 10-percentile point increase in actual Black population on highway construction outcomes. All specifications include the 1940 population of the receiving city, the share of the labor force in manufacturing, and state fixed effects. Standard errors are clustered at the city level. ${ }^{* * *} \mathrm{p}<0.01,{ }^{* *} \mathrm{p}<0.05$, ${ }^{*} \mathrm{p}<0.1$. 
Table 7: Effects of Black Migration on Local Public Finances - Housing and Community Dev.

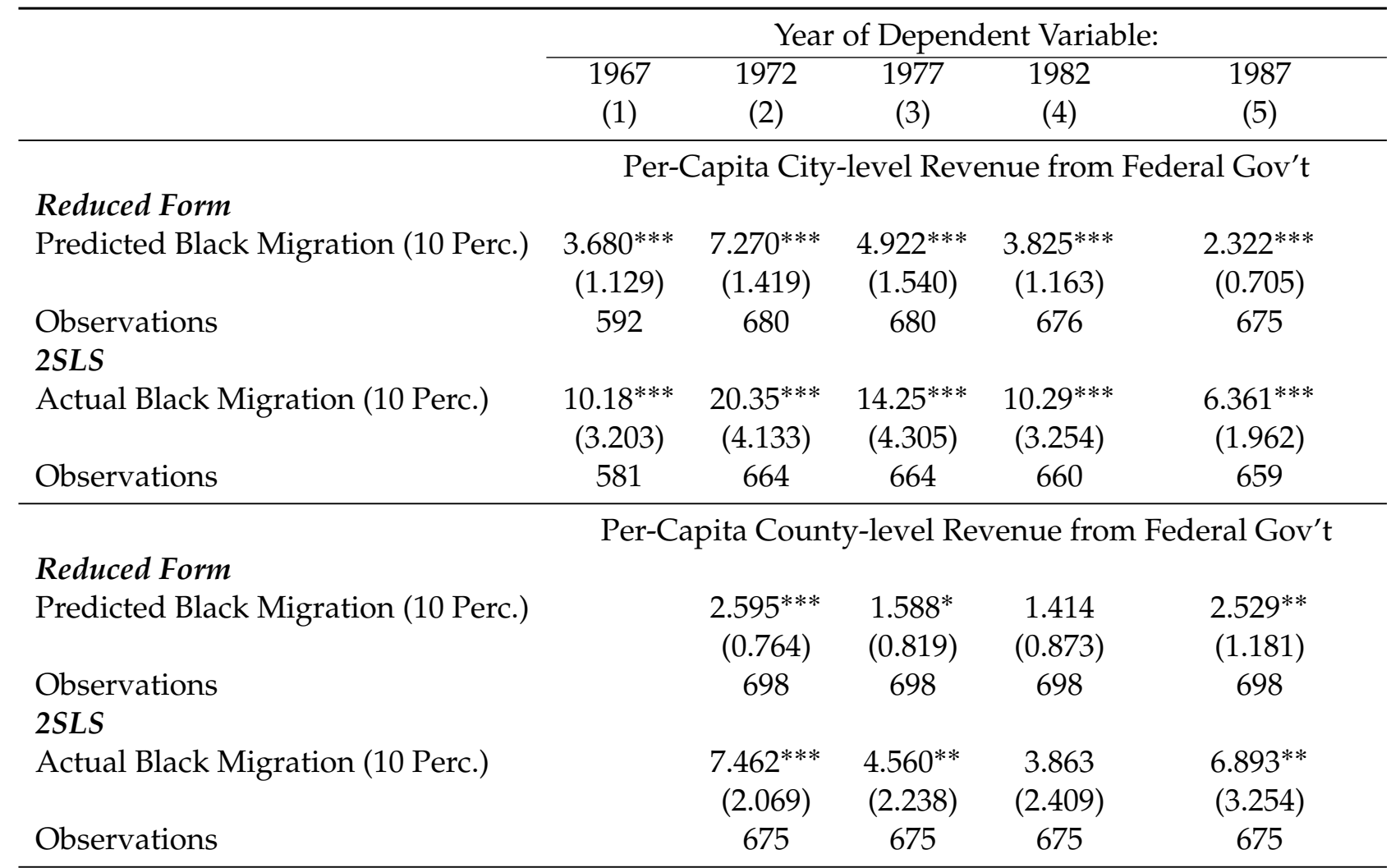

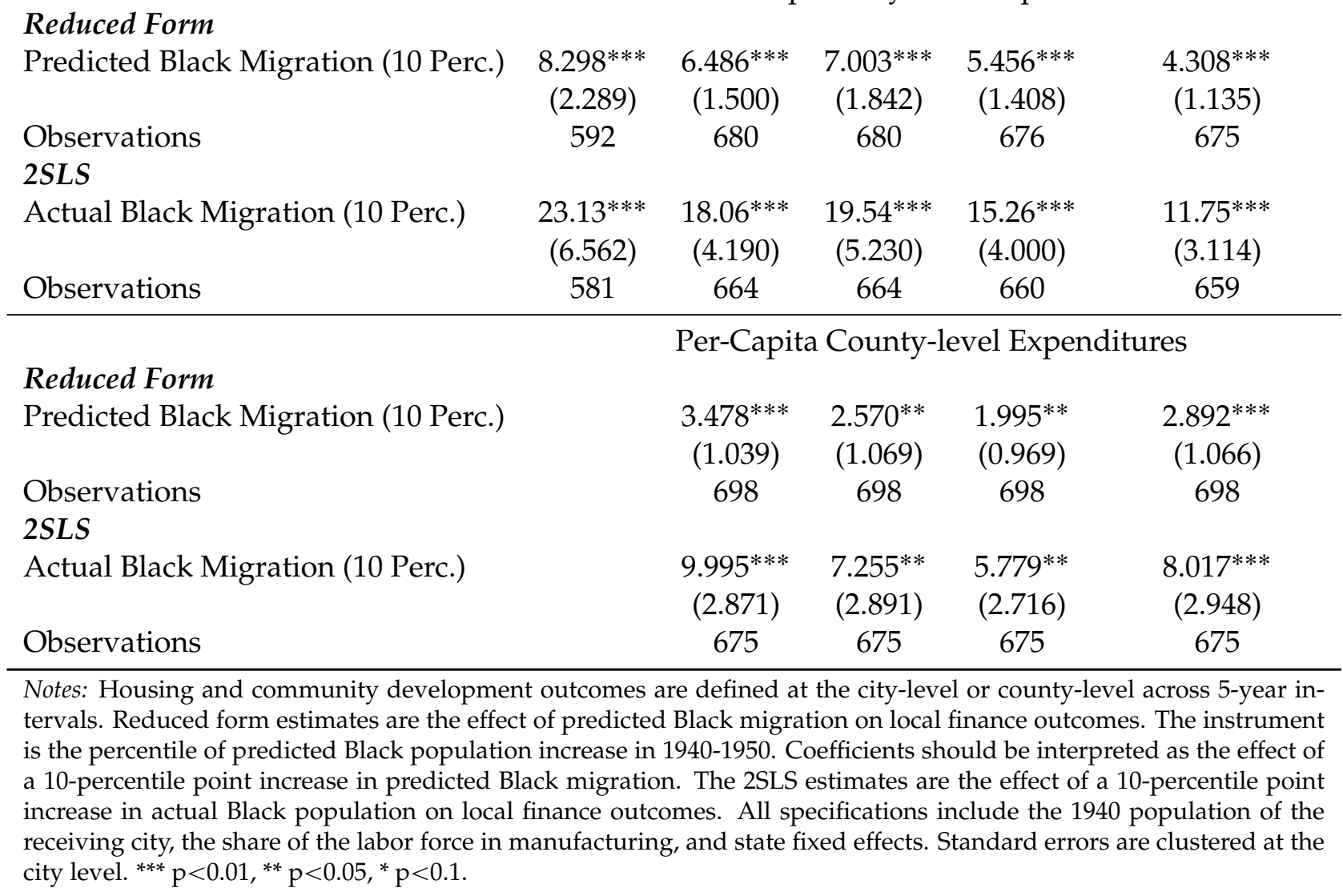




\section{APPENDIX}

Table A1: Summary Statistics - Project-Level Characteristics

\begin{tabular}{lcccc}
\hline & \multicolumn{2}{c}{ All projects } & \multicolumn{2}{c}{ Outside of South } \\
\cline { 2 - 5 } & Mean & Std. Dev. & Mean & Std. Dev. \\
\hline Estimated displacement: Total no. of White families & 151 & 283 & 174 & 313 \\
Estimated displacement: Total no. of non-White families & 195 & 398 & 207 & 444 \\
Estimated clearance: Total no. of substandard units & 340 & 632 & 371 & 704 \\
Estimated clearance: Total no. of standard units & 90 & 230 & 107 & 261 \\
Project land total acres & 5.3 & 10 & 4.9 & 11 \\
Project land acres for residential use & 2.7 & 5 & 2.3 & 4.9 \\
\hline
\end{tabular}

Notes: 913 projects had non-missing data on planned displacement for White families. The sample outside of the South contains 677 projects. 
Table A2: Effect of Black Migration on Additional Urban Renewal Characteristics

\begin{tabular}{|c|c|c|c|c|c|c|c|}
\hline & \multicolumn{7}{|c|}{ Project Land Acreage: } \\
\hline & $\begin{array}{c}\text { Total } \\
(1)\end{array}$ & $\begin{array}{l}\% \text { of City Area } \\
\text { (2) }\end{array}$ & $\begin{array}{l}\text { Residential } \\
\text { (3) }\end{array}$ & $\begin{array}{c}\text { Commercial } \\
\text { (4) }\end{array}$ & $\begin{array}{c}\text { Industrial } \\
(5)\end{array}$ & $\begin{array}{l}\text { Streets } \\
\text { (6) }\end{array}$ & $\begin{array}{l}\text { Public } \\
\text { (7) }\end{array}$ \\
\hline \multicolumn{8}{|l|}{ Reduced Form } \\
\hline Predicted Black Migration (10 Perc.) & $\begin{array}{c}0.868^{* * *} \\
(0.229)\end{array}$ & $\begin{array}{c}0.0000798^{* * *} \\
(0.0000184)\end{array}$ & $\begin{array}{c}0.296 * * * \\
(0.0923)\end{array}$ & $\begin{array}{l}0.110 * * * \\
(0.0252)\end{array}$ & $\begin{array}{c}0.189 * * * \\
(0.0669)\end{array}$ & $\begin{array}{c}0.221^{* * *} \\
(0.0589)\end{array}$ & $\begin{array}{l}0.140^{* *} \\
(0.0660)\end{array}$ \\
\hline Observations & 705 & 692 & 705 & 705 & 705 & 705 & 705 \\
\hline \multicolumn{8}{|l|}{$2 S L S$} \\
\hline Actual Black Migration (10 Perc.) & $\begin{array}{c}2.380 * * * \\
(0.606)\end{array}$ & $\begin{array}{l}0.000215^{* * *} \\
(0.0000548)\end{array}$ & $\begin{array}{c}0.817 * * * \\
(0.250)\end{array}$ & $\begin{array}{l}0.302 * * * \\
(0.0640)\end{array}$ & $\begin{array}{c}0.520 * * * \\
(0.182)\end{array}$ & $\begin{array}{c}0.603 * * * \\
(0.154)\end{array}$ & $\begin{array}{c}0.383^{* *} \\
(0.183)\end{array}$ \\
\hline Observations & 682 & 672 & 682 & 682 & 682 & 682 & 682 \\
\hline $\begin{array}{l}\text { Notes: Reduced form estimates are the effect } \\
\text { population increase in } 1940-1950 \text {, defined as } \\
\text { predicted by southern economic factors alon } \\
\text { The 2SLS estimates are the effect of a 10-per } \\
1940 \text { population of the receiving city, the shar } \\
p<0.01 \text {,** } p<0.05, * p<0.1 \text {. }\end{array}$ & $\begin{array}{l}\text { of predicted } \\
\text { the interacti } \\
\text { Coefficients } \\
\text { centile point } \\
\text { e of the labor }\end{array}$ & $\begin{array}{l}\text { 3lack migration on u } \\
\text { on between pre- } 1940 \\
\text { should be interprete } \\
\text { increase in actual B } \\
\text { force in manufactur }\end{array}$ & $\begin{array}{l}\text { ban renewal out } \\
\text { Black southern } \\
\text { d as the effect of } \\
\text { ck population o } \\
\text {, and state fixe }\end{array}$ & $\begin{array}{l}\text { comes. The instr } \\
\text { migration patter } \\
\text { a } 10 \text {-percentile p } \\
\text { n urban renewa }\end{array}$ & $\begin{array}{l}\text { ment is the } \mathrm{p} \\
\text { and post-19 } \\
\text { t increase in } \\
\text { utcomes. A }\end{array}$ & $\begin{array}{l}\text { entile of } \mathrm{p} \\
\text { outflows } \mathrm{c} \\
\text { redicted } \mathrm{Bl} \text {. } \\
\text { pecificatior }\end{array}$ & $\begin{array}{l}\text { licted Black } \\
\text { migrants as } \\
\text { migration. } \\
\text { include the } \\
\text { ty level. }\end{array}$ \\
\hline
\end{tabular}


Table A3: Effects of Black Migration on Housing Characteristics

\begin{tabular}{lccc}
\hline & \multicolumn{3}{c}{ Dependent variables (Change from 1950 to 1960): } \\
\cline { 2 - 4 } & $\begin{array}{c}\text { Total Dwelling } \\
\text { Units }\end{array}$ & $\begin{array}{c}\text { Perc. in Single-Unit } \\
\text { Detached Structures }\end{array}$ & $\begin{array}{c}\text { Perc. with Hot Running } \\
\text { Water and Private Bath }\end{array}$ \\
\cline { 2 - 4 } & $(1)$ & $(2)$ & $(3)$ \\
\hline Reduced Form & & & -0.0918 \\
Predicted Black Migration (10 Perc.) & $-518.3^{*}$ & -0.147 & $(0.110)$ \\
& $(285.4)$ & $(0.247)$ & 315 \\
Observations & 315 & 314 & \\
2SLS & & & -0.328 \\
Actual Black Migration (10 Perc.) & $-1853.9^{*}$ & -0.515 & $(0.392)$ \\
Observations & $(1080.9)$ & $(0.909)$ & 311 \\
\hline
\end{tabular}

Notes: Outcome variables come from the 1944-1977 County and City Data Book. Reduced form estimates are the effect of predicted Black migration on urban renewal outcomes. The instrument is the percentile of predicted Black population increase in 1940-1950, defined as the interaction between pre-1940 Black southern migration patterns and post-1940 outflows of migrants as predicted by southern economic factors alone. Coefficients should be interpreted as the effect of a 10-percentile point increase in predicted Black migration. The 2SLS estimates are the effect of a 10-percentile point increase in actual Black population on urban renewal outcomes. All specifications include the 1940 population of the receiving city, the share of the labor force in manufacturing, and state fixed effects. Standard errors are clustered at the city level. ${ }^{* * *} \mathrm{p}<0.01,{ }^{* *} \mathrm{p}<0.05,{ }^{*} \mathrm{p}<0.1$. 
Table A4: Effects of Black Migration on Local Public Finances - Police Expenditures

\begin{tabular}{|c|c|c|c|c|c|}
\hline & \multicolumn{5}{|c|}{ Year of Dependent Variable: } \\
\hline & $\begin{array}{c}1967 \\
(1)\end{array}$ & $\begin{array}{c}1972 \\
(2)\end{array}$ & $\begin{array}{c}1977 \\
(3)\end{array}$ & $\begin{array}{c}1982 \\
(4)\end{array}$ & $\begin{array}{c}1987 \\
(5)\end{array}$ \\
\hline & \multicolumn{5}{|c|}{ Per-Capita City-level Expenditures } \\
\hline \multicolumn{6}{|l|}{ Reduced Form } \\
\hline Predicted Black Migration (10 Perc.) & $\begin{array}{c}2.573^{* * *} \\
(0.619)\end{array}$ & $\begin{array}{c}4.896^{* * *} \\
(1.108)\end{array}$ & $\begin{array}{c}5.436^{* * *} \\
(0.885)\end{array}$ & $\begin{array}{c}4.450^{* * * *} \\
(0.930)\end{array}$ & $\begin{array}{c}4.036^{* * *} \\
(1.400)\end{array}$ \\
\hline Observations & 592 & 680 & 680 & 676 & 675 \\
\hline \multicolumn{6}{|l|}{$2 S L S$} \\
\hline Actual Black Migration (10 Perc.) & $\begin{array}{c}7.681^{* * * *} \\
(1.561)\end{array}$ & $\begin{array}{c}13.79^{* * * *} \\
(3.068)\end{array}$ & $\begin{array}{c}15.16^{* * *} \\
(2.349)\end{array}$ & $\begin{array}{c}12.46^{* * *} \\
(2.477)\end{array}$ & $\begin{array}{c}11.41^{* * *} \\
(3.751)\end{array}$ \\
\hline \multirow[t]{2}{*}{ Observations } & 581 & 664 & 664 & 660 & 659 \\
\hline & \multicolumn{5}{|c|}{ Per-Capita County-level Expenditures } \\
\hline \multicolumn{6}{|l|}{ Reduced Form } \\
\hline Predicted Black Migration (10 Perc.) & & $\begin{array}{c}3.554^{* * *} \\
(0.949)\end{array}$ & $\begin{array}{c}4.271^{* * *} \\
(1.015)\end{array}$ & $\begin{array}{c}4.032 * * * \\
(0.952)\end{array}$ & $\begin{array}{c}4.695^{* * *} \\
(1.129)\end{array}$ \\
\hline Observations & & 698 & 698 & 698 & 698 \\
\hline \multicolumn{6}{|l|}{$2 S L S$} \\
\hline Actual Black Migration (10 Perc.) & & $\begin{array}{c}9.911^{* * *} \\
(2.685)\end{array}$ & $\begin{array}{c}11.77^{* * *} \\
(2.885)\end{array}$ & $\begin{array}{c}11.19^{* * *} \\
(2.722)\end{array}$ & $\begin{array}{c}12.99 * * * \\
(3.179)\end{array}$ \\
\hline Observations & & 675 & 675 & 675 & 675 \\
\hline \multicolumn{6}{|c|}{$\begin{array}{l}\text { Notes: Police expenditure outcomes are defined at the city-level or county-level across 5-year intervals. Reduced } \\
\text { form estimates are the effect of predicted Black migration on local finance outcomes. The instrument is the } \\
\text { percentile of predicted Black population increase in 1940-1950. Coefficients should be interpreted as the effect of } \\
\text { a 10-percentile point increase in predicted Black migration. The 2SLS estimates are the effect of a } 10 \text {-percentile } \\
\text { point increase in actual Black population on local finance outcomes. All specifications include the } 1940 \text { population } \\
\text { of the receiving city, the share of the labor force in manufacturing, and state fixed effects. Standard errors are } \\
\text { clustered at the city level. }{ }^{* * *} \mathrm{p}<0.01,{ }^{* *} \mathrm{p}<0.05,{ }^{*} \mathrm{p}<0.1 \text {. }\end{array}$} \\
\hline
\end{tabular}


Table A5: Effects of Black Migration on Local Public Finances - Utility Expenditures

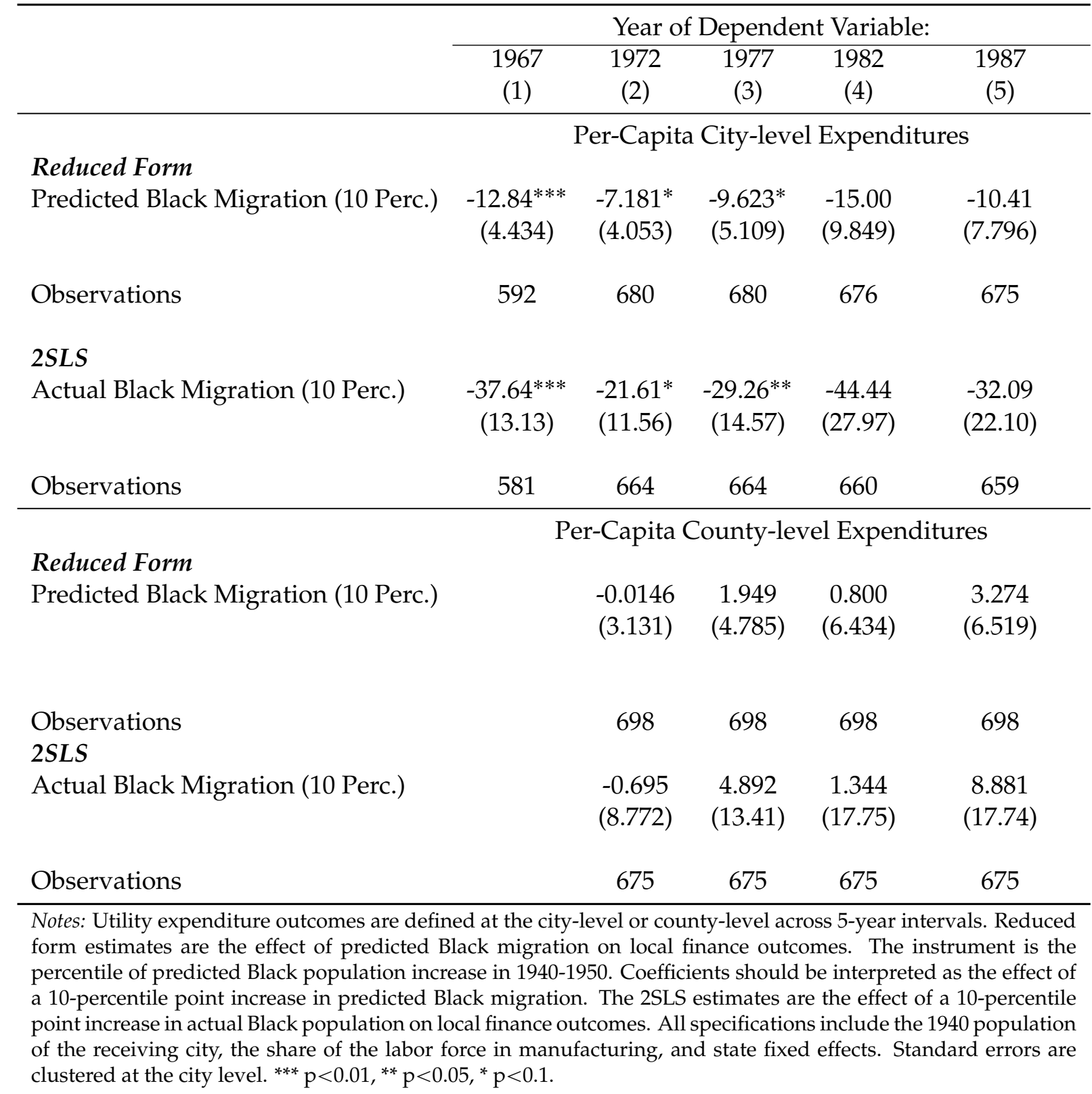


Table A6: Effects of Black Migration on Local Public Finances - Education Expenditures

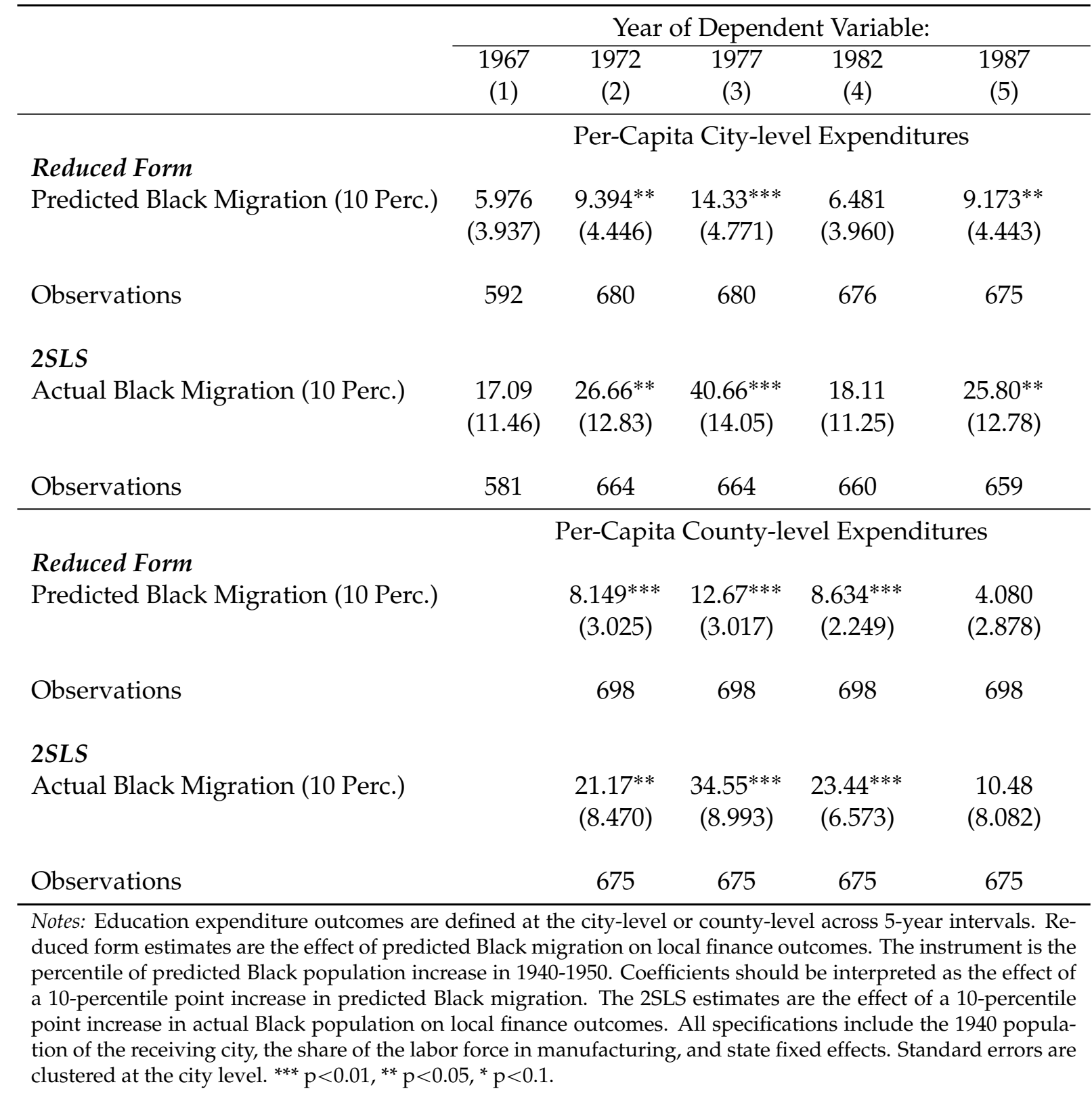


Table A7: Relationship between Southern White Migration and Urban Renewal

\begin{tabular}{|c|c|c|c|c|c|c|c|}
\hline & \multirow[b]{2}{*}{$\begin{array}{l}\text { Any UR Project } \\
\text { (1) }\end{array}$} & \multicolumn{2}{|c|}{ Family Displacement: } & \multicolumn{2}{|c|}{ Dwelling Unit Clearance: } & \multicolumn{2}{|c|}{ Project Land Acreage: } \\
\hline & & $\begin{array}{l}\text { White } \\
\text { (2) }\end{array}$ & $\begin{array}{l}\text { Non-White } \\
\text { (3) }\end{array}$ & $\begin{array}{l}\text { Substandard } \\
\text { (4) }\end{array}$ & $\begin{array}{l}\text { Standard } \\
\text { (5) }\end{array}$ & $\begin{array}{c}\text { Total } \\
(6)\end{array}$ & $\begin{array}{l}\text { Residential } \\
\text { (7) }\end{array}$ \\
\hline White Migration (10 Perc.) & $\begin{array}{l}-0.004 \\
(0.006)\end{array}$ & $\begin{array}{l}-0.199 \\
(4.319)\end{array}$ & $\begin{array}{l}-2.078 \\
(14.01)\end{array}$ & $\begin{array}{c}12.76 \\
(16.00)\end{array}$ & $\begin{array}{l}-10.23 \\
(8.899)\end{array}$ & $\begin{array}{l}-0.387 \\
(0.301)\end{array}$ & $\begin{array}{l}-0.125 \\
(0.110)\end{array}$ \\
\hline Observations & 673 & 673 & 673 & 673 & 673 & 673 & 673 \\
\hline
\end{tabular}

Notes: Explanatory variable of interest is actual White migration from the South into cities in the north and west in 1940-1950. All specifications include the percentile of actual Black migration from 1940-1950, the 1940 population of the receiving city, the share of the labor force in manufacturing, and state fixed effects. Standard errors are clustered at the city level. ${ }^{* * *} \mathrm{p}<0.01,{ }^{* *} \mathrm{p}<0.05,{ }^{*} \mathrm{p}<0.1$. 
Table A8: Effect of Black Migration, Accounting for European Mass Migration

\begin{tabular}{|c|c|c|c|c|c|c|c|c|c|c|}
\hline & \multirow{2}{*}{\multicolumn{2}{|c|}{ Any UR Project }} & \multicolumn{4}{|c|}{ Family Displacement: } & \multicolumn{4}{|c|}{ Clearance of Dwelling Units: } \\
\hline & & & \multicolumn{2}{|c|}{ White } & \multicolumn{2}{|c|}{ Non-White } & \multicolumn{2}{|c|}{ Substandard } & \multicolumn{2}{|c|}{ Standard } \\
\hline & $(1)$ & $(2)$ & (3) & $(4)$ & (5) & (6) & $(7)$ & $(8)$ & (9) & $(10)$ \\
\hline \multicolumn{11}{|l|}{ Reduced Form } \\
\hline Predicted Black Migration (10 Perc.) & $\begin{array}{c}0.0370 * * * \\
(0.00572)\end{array}$ & $\begin{array}{c}0.0372 * * * \\
(0.00577)\end{array}$ & $\begin{array}{c}14.02 * * \\
(6.056)\end{array}$ & $\begin{array}{c}14.03^{* *} \\
(6.150)\end{array}$ & $\begin{array}{c}31.57^{* * *} \\
(10.53)\end{array}$ & $\begin{array}{c}29.51^{* * *} \\
(9.874)\end{array}$ & $\begin{array}{c}32.87^{* *} \\
(13.14)\end{array}$ & $\begin{array}{c}30.96^{* *} \\
(12.83)\end{array}$ & $\begin{array}{c}19.16^{* * *} \\
(7.100)\end{array}$ & $\begin{array}{c}19.00 * * * \\
(6.973)\end{array}$ \\
\hline Pred. European Migration (10 Perc.) & & $\begin{array}{r}-0.00343 \\
(0.0119)\end{array}$ & & $\begin{array}{c}-0.0490 \\
(4.814)\end{array}$ & & $\begin{array}{l}34.18^{*} \\
(19.67)\end{array}$ & & $\begin{array}{c}31.84 \\
(23.44)\end{array}$ & & $\begin{array}{c}2.694 \\
(6.391)\end{array}$ \\
\hline Observations & 698 & 698 & 698 & 698 & 698 & 698 & 698 & 698 & 698 & 698 \\
\hline \multicolumn{11}{|l|}{$2 S L S$} \\
\hline Actual Black Migration (10 Perc.) & $\begin{array}{c}0.0999 * * * \\
(0.0147)\end{array}$ & $\begin{array}{c}0.101^{* * *} \\
(0.0152)\end{array}$ & $\begin{array}{c}37.47^{* *} \\
(16.35)\end{array}$ & $\begin{array}{c}37.84^{* *} \\
(16.91)\end{array}$ & $\begin{array}{c}87.91^{* * *} \\
(28.96)\end{array}$ & $\begin{array}{c}81.05^{* * *} \\
(27.09)\end{array}$ & $\begin{array}{c}90.07^{* *} \\
(35.91)\end{array}$ & $\begin{array}{c}83.75^{* *} \\
(35.26)\end{array}$ & $\begin{array}{c}52.40^{* * *} \\
(18.77)\end{array}$ & $\begin{array}{c}52.20 * * * \\
(18.51)\end{array}$ \\
\hline Pred. European Migration (10 Perc.) & & $\begin{array}{r}-0.00497 \\
(0.0126)\end{array}$ & & $\begin{array}{l}-1.792 \\
(6.710)\end{array}$ & & $\begin{array}{c}33.77 \\
(20.72)\end{array}$ & & $\begin{array}{c}31.10 \\
(25.73)\end{array}$ & & $\begin{array}{c}1.014 \\
(7.645)\end{array}$ \\
\hline Observations & 675 & 675 & 675 & 675 & 675 & 675 & 675 & 675 & 675 & 675 \\
\hline
\end{tabular}

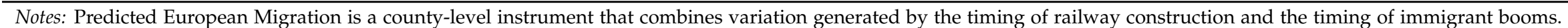
It is the decile of average predicted European immigrant share from 1860-1920. Predicted Black migration is the same instrument as before, defined as the interaction between pre-1940 Black southern migration patterns and post-1940 outflows of migrants as predicted by southern economic factors alone. All specifications include the 1940 population of the receiving city, the share of the labor force in manufacturing, and state fixed effects. Standard errors are clustered at the city level. ${ }^{* * *} \mathrm{p}<0.01,{ }^{* *} \mathrm{p}<0.05,{ }^{*} \mathrm{p}<0.1$. 